Hydrol. Earth Syst. Sci. Discuss., 8, 7017-7053, 2011 www.hydrol-earth-syst-sci-discuss.net/8/7017/2011/ doi:10.5194/hessd-8-7017-2011

(C) Author(s) 2011. CC Attribution 3.0 License.
Hydrology and Earth System Sciences Discussions

\title{
Estimation of baseflow parameters of variable infiltration capacity model with soil and topography properties for predictions in ungauged basins
}

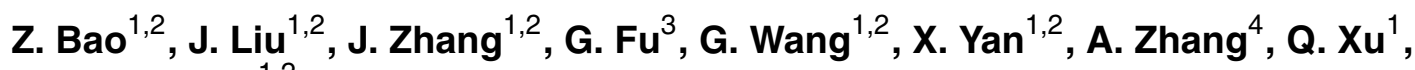
and $M$. Shang ${ }^{1,2}$

${ }^{1}$ Nanjing Hydraulic Research Institute, No. 225, Guangzhou Road, Nanjing, 210029, China

${ }^{2}$ Research Center for Climate Change, MWR, No. 225, Guangzhou Road, Nanjing, 210029, China

${ }^{3}$ CSIRO Land and Water, Private Bag 5, Wembley, WA 6913, Australia

${ }^{4}$ Faculty of Infrastructure Engineering, Dalian University of Technology, Dalian, 116024, China

Received: 17 June 2011 - Accepted: 17 June 2011 - Published: 20 July 2011

Correspondence to: Z. Bao (nhri.bzx@gmail.com, zxbao@nhri.cn)

Published by Copernicus Publications on behalf of the European Geosciences Union.

HESSD

8, 7017-7053, 2011

Estimation of baseflow parameters of variable infiltration capacity model

Z. Bao et al.

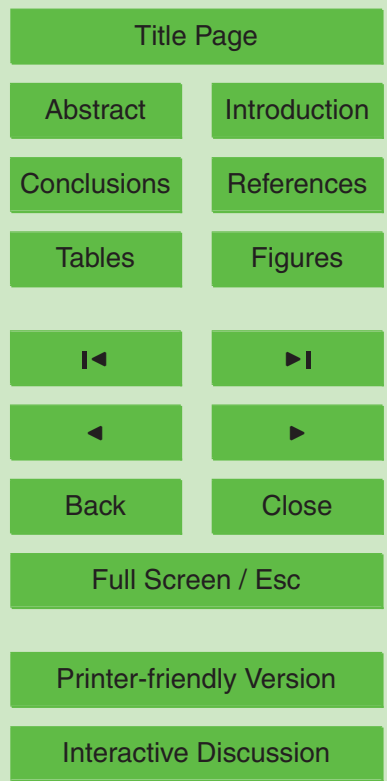

Interactive Discussion 


\section{Abstract}

Equifinality is unavoidable when transferring model parameters from gauged catchments to ungauged catchments for predictions in ungauged basins (PUB). A framework for estimating the three baseflow parameters of variable infiltration capacity (VIC) 5 model, directly with soil and topography properties is presented. When the new parameters setting methodology is used, the number of parameters needing to be calibrated is reduced from six to three, that leads to a decrease of equifinality and uncertainty. This is validated by Monte Carlo simulations in 24 hydro-climatic catchments in China. Using the new parameters estimation approach, model parameters become 10 more sensitive and the extent of parameters space will be smaller when a threshold of goodness-of-fit is given. That means the parameters uncertainty is reduced with the new parameters setting methodology. In addition, the uncertainty of model simulation is estimated by the generalised likelihood uncertainty estimation (GLUE) methodology. The results indicate that the uncertainty of streamflow simulations, i.e., confidence interval, is lower with the new parameters estimation methodology compared to that used by original calibration methodology. The new baseflow parameters estimation framework could be applied in VIC model and other appropriate models for PUB.

\section{Introduction}

The variable infiltration capacity (VIC) model is a macro-scale hydrological based land surface model (Liang et al., 1994, 1996; Liang and Xie, 2001), which is an effective tool for simulating the processes of the hydrological cycle (Maidment, 1993). Hydrological models can generate predictions of hydrological response to a range of climates for flood forecasting and regional water resources management. On the other hand, they can also provide the feedback of land surface schemes from atmosphere to general circulation models (GCMs) for numerical weather forecasting and future climatic scenarios prediction. Model parameters represent the landscape and climatic properties
HESSD

8, 7017-7053, 2011

\section{Estimation of baseflow parameters of variable infiltration capacity model}

Z. Bao et al.

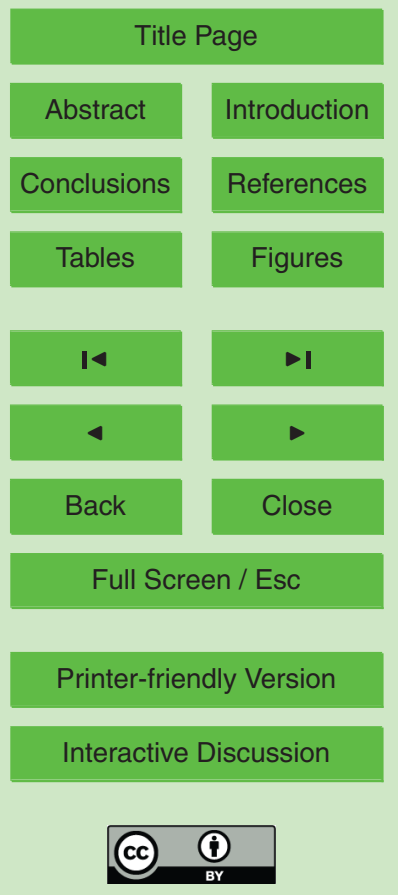


that dominate the basin response to climatic variables. Accordingly, it is critical component for the accuracy of hydrological simulation. Some studies indicate that hydrological models would have satisfying results if the model parameters are appropriately set, vice versa (Gupta et al., 1999; Wood et al., 1998). Traditionally, model parameters are 5 calibrated by optimization algorithms with some objective functions, which are calculated by simulated and observed hydrological variables. However, in many parts of the world, basins are ungauged or poorly gauged, then, there are not sufficient observed data for calibration (Sivapalan et al., 2003). Therefore, Predictions in Ungauged Basins (PUB) becomes a new challenge for hydrologists.

10 In a general way, PUB is studied by the transfer of model parameters from gauged catchments to ungauged catchments (Blöschl and Sivapalan, 1995; Sivapalan et al., 2003). Three kinds of approaches are widely used: regression, spatial proximity, and physical similarity (Oudin et al., 2008; Zhang and Chiew, 2009). Probably, regressionbased approach is most popular, has a long history, and has been studied widely (Ab15 dulla and Lettenmaier, 1997; Hundecha et al., 2007; Jarboe and Haan, 1974; Weeks and Ashkenasy, 1985; Weeks and Boughton, 1987; Young, 2006). The key step of this methodology is to construct nonlinear relationships between optimized model parameters and catchment characteristics (e.g., soil, vegetation, climate, topography, etc.) with regression equations. However, there are complex correlations between model parameters and catchment characteristics (Wagener, 2007). Hence, it is not straightforward to investigate the actual nonlinear relationship between model parameters and catchment characteristics by simple multiple regression equations. Meanwhile, model parameters may change and only represent transient catchment characteristics, as a result of land use/cover change (LUCC) and climatic variation (Brown et al., 2005; Lubès-Niel et al., 2003; Merz et al., 2011). Thereby, it is difficult to calibrate parameters changing with time (Wagener et al., 2010). Due to above limitations, regression-based approach generally results in large errors, when they are verified in other catchments, and have been criticized by some studies (Bardossy, 2007; Huang et al., 2003; Parajka et al., 2007).
HESSD

$8,7017-7053,2011$

\section{Estimation of baseflow parameters of variable infiltration capacity model}

Z. Bao et al.

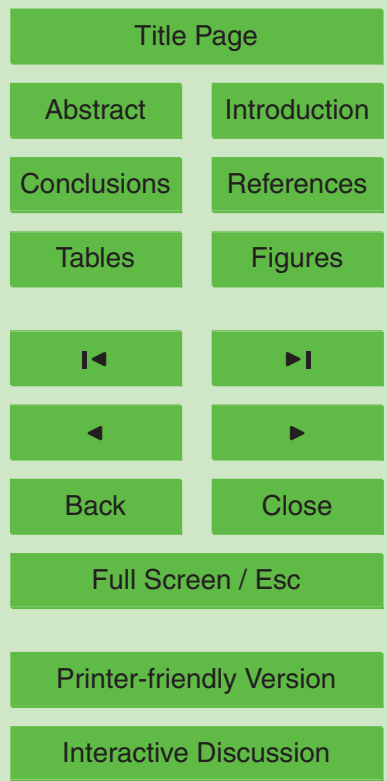


Spatial proximity and physical similarity approaches have been more and more popularly used in recent studies (Bardossy, 2007; Merz and Blöschl, 2004; Parajka et al., 2005; Samuel et al., 2011). In the former, model parameters in ungauged catchments are estimated by interpolation techniques, e.g. inverse distance weighted and kriging, 5 with calibrated parameters from the geographically closest gauged catchments. This approach depends on a hypothesis, that regional catchments are relatively homogeneous and have similar characteristics. The latter approach transfers model parameters from gauged physically similar catchments, which are defined by some similarity indices, e.g. a cosine-pattern similarity and an Euclidean distance. Some studies have 10 been made to compare the three approaches, and attempt to investigate which is the best one, but unfortunately they do not have consistent results (Kay et al., 2006; Mclntyre et al., 2005; Oudin et al., 2008; Young, 2006; Zhang and Chiew, 2009).

However, there is an unavoidable limitation about the above three approaches, i.e. calibration-transfer-based methodology: it is difficult to find an authentic parameters 5 set for a gauged catchment. First, it is difficult to investigate the global optimized value under high dimensional parameter space, as a result of multiple local optima and curving multidimensional ridges, etc. (Gan and Biftu, 1996; Vrugt et al., 2003). Second, equifinality is unavoidable due to the cross-correlation among parameters (Beven and Binley, 1992; Beven and Freer, 2001). Probably, there is not a unique "best" parameters set, i.e., hydrological model has similar performance with different parameters set during calibration. But it may lead to considerable uncertainty in model output for verification and forecasting. Third, calibrated model parameters are sensitive to model input, because of the compensation effect of calibration parameters to model structure problems and data problems (Blöschl et al., 2007; Merz et al., 2011). For example, Wagener et al. (2003), Juston et al. (2009), and Merz et al. (2011) all investigated different parameters set for different calibration periods.

Some studies were attempted to evolve approaches for estimating model parameters in ungauged catchments. One approach is to estimate model parameters directly by catchment characteristics based on their physical definition without traditionally
HESSD

8, 7017-7053, 2011

\section{Estimation of baseflow parameters of variable infiltration capacity model}

Z. Bao et al.

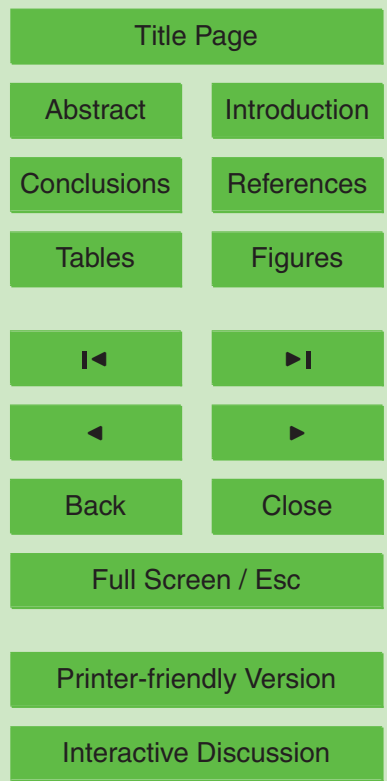


hydrological calibration. For example, Huang et al. (2003) presented a framework to transfer the $b$-parameter of VIC model from data-rich areas to data-sparse areas. First, they classified soil data obtained from the State Soil Geographic (STATSGO) database, into clusters by a self-organizing map neural network (Kohonen, 1989) and the $K$ 5 means clustering method (MacQueen, 1967). Whereafter, highly nonlinear relationships between the $b$-parameter and soil properties were constructed by a supervised neural network based on a Bayesian regularization method (Foresee and Hagan, 1997; MacKay, 1992). A case study at Illinois River basin near Watts indicated encouraging simulated streamflow compare to the observations, by the presented $b$-parameter 10 transferability framework using soil data from Arkansas, California, Oklahoma, and Texas. Another approach is to modify model structure to reduce the number of model parameters. Huang and Liang (2006) replaced the original baseflow formulation of VIC model by the concept of kinematic wave and hydrologic similarity to reduce the number of baseflow parameters from three to one needed to be calibrated. That also reduced the impacts of parameters uncertainties on model simulations.

The main objective of this study is to construct a new framework for estimating baseflow parameters of VIC model directly from soil and topography properties, without calibration. In addition, uncertainty of model parameters and output is quantitatively estimated by the generalised likelihood uncertainty estimation (GLUE; Beven and Binley, 1992; Beven and Freer, 2001). The remaining sections of this paper are organized as follows: In Sect. 2, a brief review of the VIC model and GLUE methodology is provided. Section 3 describes a new framework for estimating base flow parameters of VIC model directly from catchments physical properties of soil and topography. In Sect. 4, hydrological simulation, parameters sensitivity and uncertainty analysis, and streamflow simulation uncertainty are compared by the new methodology and original calibration approach in 24 sub-catchments in China. The conclusions are summarized in Sect. 5.

\section{HESSD}

8, 7017-7053, 2011

\section{Estimation of baseflow parameters of variable infiltration capacity model}

Z. Bao et al.

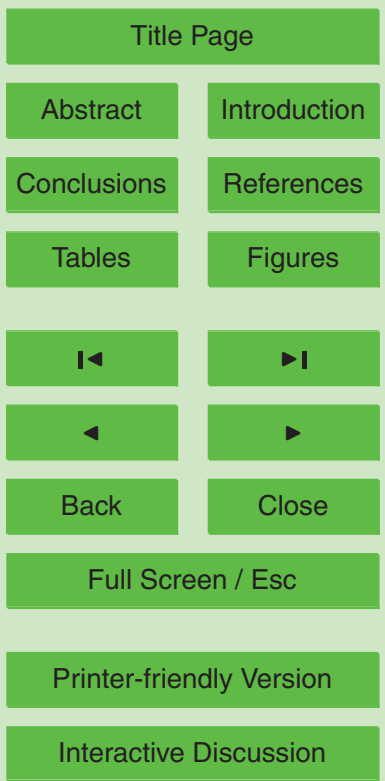




\section{Hydrological model and uncertainty analysis}

\subsection{A brief review of the VIC model}

HESSD

VIC model is a semi-distributed macro-scale hydrological based land surface model, which can balance both the water and surface energy budgets within the grid cell. The 5 key characters of VIC model are the representation of multiple land cover types, spatial variability of soil moisture capacity, soil water moving between three soil layers, surface flow considering both infiltration excess and saturation excess, and non-linear base flow. With refined describing of hydrologic process on land surface and finer performance of streamflow simulation, VIC has been applied in a number of catchments over the world (Abdulla et al., 1996; Lohmann et al., 1998; Shi et al., 2008; Su et al., 2005; Zhu and Lettenmaier, 2007).

In VIC model, surface runoff generating from the upper two soil layers, is accounted based on the variable soil moisture capacity curve which is described by the Xinanjiang model, in order to represent the sub-grid spatial variability in soil moisture capacity 15 (Zhao et al., 1980; Zhao, 1992). That is expressed as:

$W=W_{\mathrm{mm}}\left(1-(1-A)^{1 / b}\right)$

where $W$ and $W_{\mathrm{mm}}$ are the point and maximum point soil moisture capacity, respectively; $A$ is the fraction of area for which the soil moisture capacity is less than $W$; and $b$ is the soil moisture capacity shape parameter. The surface runoff, $Q_{s}$, could be calculated as:

$Q_{\mathrm{s}}=\left\{\begin{array}{l}\mathrm{PE}-\left(W_{\mathrm{m}}-W_{0}\right), \mathrm{PE}+W \geq W_{\mathrm{mm}} \\ \mathrm{PE}-\left(W_{\mathrm{m}}-W_{0}\right)+W_{\mathrm{m}}\left(1-\frac{\mathrm{PE}+W}{W_{\mathrm{mm}}}\right)^{1+b}, \mathrm{PE}+W<W_{\mathrm{mm}}\end{array}\right.$

where PE is effective precipitation, and is precipitation minus evapotranspiration; $W_{\mathrm{m}}$ is soil moisture capacity of the upper two soil layers; $W_{0}$ is initial soil moisture.

\section{Estimation of} baseflow parameters of variable infiltration capacity model

Z. Bao et al.

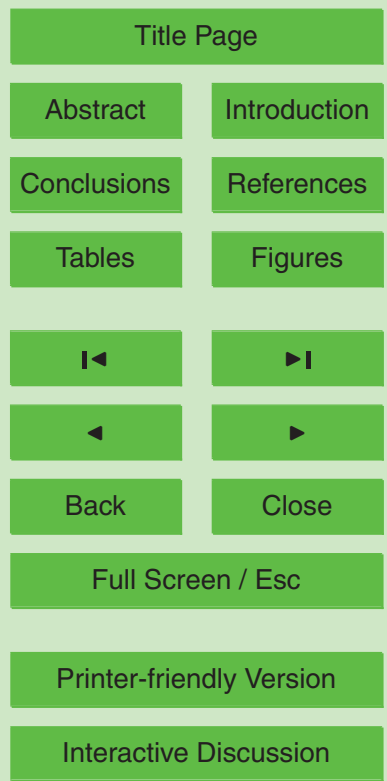


Using the Arno model formulation (Franchini and Pacciani, 1991; Todini, 1996), base flow (sub surface runoff) from the third soil layer is expressed as (Fig. 1):

$Q_{\mathrm{b}}=\left\{\begin{array}{l}\frac{D_{\mathrm{s}} D_{\mathrm{m}}}{W_{\mathrm{s}} \theta_{3, \mathrm{~s}}} \theta_{3}, 0 \leq \theta_{3} \leq W_{\mathrm{s}} \theta_{3, \mathrm{~s}} \\ \frac{D_{\mathrm{s}} D_{\mathrm{m}}}{W_{\mathrm{s}} \theta_{3, \mathrm{~s}}} \theta_{3}+\left(D_{\mathrm{m}}-\frac{D_{\mathrm{s}} D_{\mathrm{m}}}{W_{\mathrm{s}}}\right)\left(\frac{\theta_{3}-W_{\mathrm{s}} \theta_{3, \mathrm{~s}}}{\theta_{3, \mathrm{~s}}-W_{\mathrm{s}} \theta_{3, \mathrm{~s}}}\right)^{2}, \theta_{3}>W_{\mathrm{s}} \theta_{3, \mathrm{~s}}\end{array}\right.$

where $D_{\mathrm{m}}$ is the maximum subsurface flow; $D_{\mathrm{s}}$ and $W_{\mathrm{s}}$ are the fraction of $D_{\mathrm{m}}$ and 5 maximum soil moisture of third layer $\left(\theta_{3, \mathrm{~s}}\right)$, respectively; and $\theta_{3}$ is the current soil moisture of third layer. The base flow recession curve is linear and nonlinear below and above a threshold $\left(W_{\mathrm{s}} \theta_{3, \mathrm{~s}}\right)$, respectively.

In VIC model, there are six parameters needing to be calibrated (Table 1). That includes the three baseflow parameters: $W_{\mathrm{s}}, D_{\mathrm{s}}$, and $D_{\mathrm{m}}$; variable soil moisture capacity 10 curve parameter: $b$; and two parameters, $d_{2}$ and $d_{3}$, that controls the thickness of the second and third soil layer, respectively. The six parameters are calibrated by two objectives: Nash-Sutcliffe coefficient (Nsc) and relative error $(\mathrm{Re})$, which are defined as:

$\mathrm{Nsc}=1-\frac{\sum\left(Q_{\mathrm{obs}}-Q_{\mathrm{sim}}\right)^{2}}{\sum\left(Q_{\mathrm{obs}}-\bar{Q}_{\mathrm{obs}}\right)^{2}}$

$15 \mathrm{Re}=\frac{R_{\mathrm{sim}}-R_{\mathrm{obs}}}{R_{\mathrm{obs}}} \times 100 \%$

where $Q_{\mathrm{obs}}$ and $\mathrm{Q}_{\mathrm{sim}}$ are the observed and simulated streamflow, respectively; $\bar{Q}_{\mathrm{obs}}$ is the mean value of $Q_{\mathrm{obs}} ; R_{\mathrm{obs}}$ and $R_{\text {sim }}$ are the observed and simulated average annual streamflow, respectively. For more information on the VIC model, the reader is referred to the VIC web-site, http://www.hydro.washington.edu/Lettenmaier/Models/VIC.

\subsection{Generalised likelihood uncertainty estimation}

GLUE methodology is an innovative uncertainty estimation approach introduced by Beven and Binley (1992), and has been applied in many researches (Hunter et al., 7023
HESSD

8, 7017-7053, 2011

Estimation of baseflow parameters of variable infiltration capacity model

Z. Bao et al.

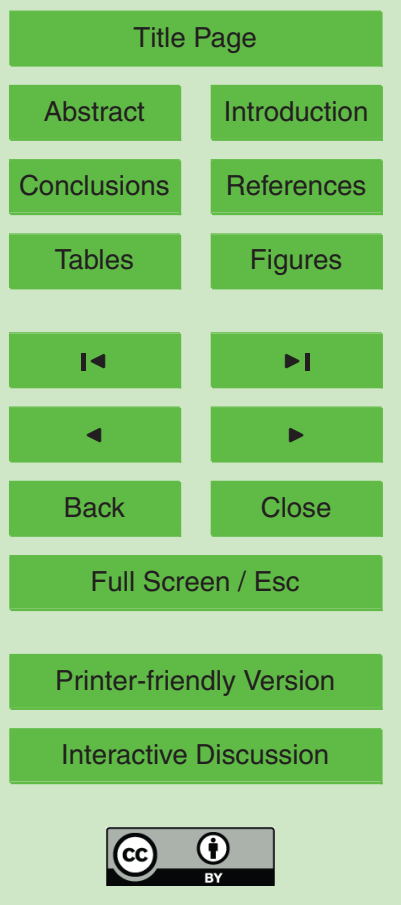


2005; Khu and Werner, 2003; Montanari, 2005; Morse and Pohll, 2003; Rojas et al., 2010; Stedinger et al., 2008; Zheng and Keller, 2007). Based on the concept of equifinality (Beven, 2006; Beven and Freer, 2001) and Bayesian theory, GLUE methodology is an extension of generalized sensitivity analysis (GSA; Hornberger and Spear, 1981; 5 Sepear and Hornberger, 1980), and can estimate parameter uncertainty explicitly, using Monte Carlo (MC) method. In this study, GLUE methodology is applied in the following steps:

1. Based on the MC simulation, VIC model is run with a number of parameters set, the prior probability of which is uniform distribution.

2. The likelihood measure, a measure of goodness-of-fit, is calculated by the observations and simulations in every parameter set. Usually, Nsc is used as the likelihood measure. In order to consider both Nsc and Re, a modified likelihood measure, Mnc indicator, is used in this study:

$\mathrm{Mnc}=\frac{\mathrm{Nsc}+1-\mathrm{Abs}(\mathrm{Re})}{2}$

3. When the likelihood value is under a given threshold, the parameters set is considered as "nonbehavioral" and is rejected. Then, the likelihoods of the remaining parameters sets are rescaled with a cumulative sum of 1 . That is defined as likelihood weight looked like probability, and is regarded as the posterior parameters probability distribution.

4. Estimate the confidence interval of streamflow at each time step for uncertainty analysis, by quantiles ranked in ascending order with likelihood weight.

In addition of confidence interval, a quantitative estimator is used for uncertainty analysis (probabilistic Shannon Entropy measure, H; Klir and Folger, 1988):

$H=-\sum_{i=1}^{M} l_{i} \log _{2} l_{i}$
HESSD

8, 7017-7053, 2011

Estimation of baseflow parameters of variable infiltration capacity model

Z. Bao et al.

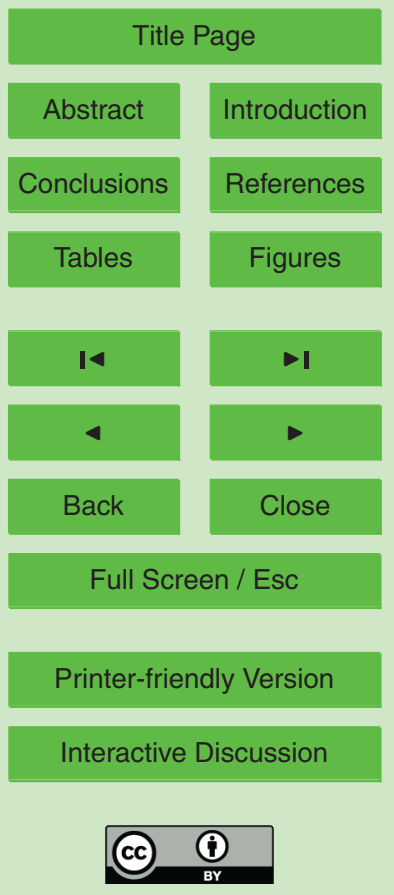




\section{A framework for estimation of baseflow parameters}

Equifinality is a critical impediment for model parameters calibration and PUB, especially for non-sensitive parameters. That is because model can perform best with 5 a more extensive range of non-sensitive parameters than sensitive parameters. In VIC model, the three baseflow parameters $\left(W_{\mathrm{s}}, D_{\mathrm{s}}\right.$, and $\left.D_{\mathrm{m}}\right)$ are less sensitive than other three parameters (Demaria et al., 2007). In this study, a framework is presented to estimate the three baseflow parameters directly from physical properties and topography.

1. $D_{\mathrm{m}}$-parameter. $D_{\mathrm{m}}$ is daily maximum subsurface flow. That occurs when the third soil layer moisture is saturated. By Darcy's Law (Darcy, 1856), $D_{\mathrm{m}}$-parameter in every sub-grid could be estimated as:

$D_{\mathrm{m}}=-K_{\mathrm{s}} \frac{\partial \Phi(x)}{\partial x}$

where $K_{\mathrm{s}}$ is saturated hydraulic conductivity, and $\partial \Phi(x) / \partial x$ is horizontal pressure gradient, that could be calculated by the sub-grid average topography slope when the soil moisture is saturated. The $K_{\mathrm{s}}$ values for several soil texture classes are referenced to Rawls et al. (1998).

2. $W_{\mathrm{s}}$-parameter. Based on unsaturated Darcy's law, the quantity of baseflow depends on unsaturated hydraulic conductivity, $K$, and pressure gradient. When the soil moisture is over than field capacity, bulk water occurs, and then baseflow increases rapidly as the increase of soil moisture. In VIC model, $W_{\mathrm{s}}$ is the inflexion of soil moisture for baseflow generation, and can be calculated as:

\section{Estimation of baseflow parameters of variable infiltration capacity model}

Z. Bao et al.

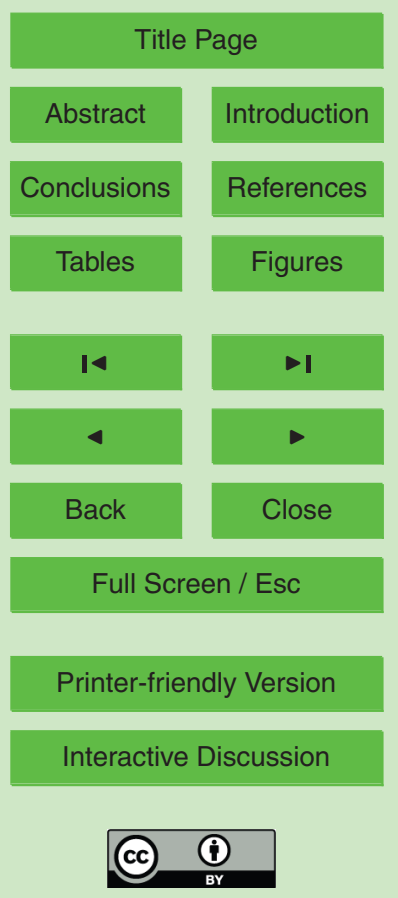


where $W_{\mathrm{f}}$ and $W_{\mathrm{m}}$ are sub-grid field capacity and saturated soil moisture, respectively.

3. $D_{\mathrm{s}}$-parameter. When the sub-grid soil moisture is $W_{\mathrm{s}} W_{\mathrm{m}}$, i.e., $W_{\mathrm{f}}$, point soil moisture, $\theta_{f}$, could be calculated by the variable soil moisture capacity curve (Fig. 2). As a fraction, $A_{0}$, soil moisture is saturated; but in the remaining fraction, $1-A_{0}$, soil moisture is $\theta_{\mathrm{f}}$ and unsaturated. In the $1-A_{0}$ fraction, unsaturated hydraulic conductivity, $K$, can be estimated by the Brooks-Corey equation (Brooks and Corey, 1964; Campbell, 1974):

$K=K_{\mathrm{s}}\left(\frac{\theta_{\mathrm{f}}}{\theta_{\mathrm{s}}}\right)^{2 \lambda+3}$

where $\lambda$ is a parameter, that is referenced to Cosby et al. (1984). As a fraction of $D_{\mathrm{m}}, D_{\mathrm{s}}$-parameter is expressed as:

$$
D_{\mathrm{s}}=A_{0}+\int_{A_{0}}^{1} \frac{K}{K_{\mathrm{s}}} d A=A_{0}+\int_{A_{0}}^{1}\left(\frac{\theta_{\mathrm{f}}}{\theta_{\mathrm{s}}}\right)^{2 b+3} d A
$$

By the above framework, the three baseflow parameters are directly estimated from physical properties and topography. The parameters can be estimated in every subgrid, and are different in different sub-grid. But using calibration methodology, parameters will be set as same value in the whole catchment. Therefore, using this framework, baseflow parameters will be distributed and more relatively authentic.

\section{Results}

\subsection{Study area and dataset}

24 sub-catchments located through China are used in this study (Fig. 3). Table 2 presents an overview of the detailed basic information for the 24 sub-catchments. The
HESSD

8, 7017-7053, 2011

Estimation of baseflow parameters of variable infiltration capacity model

Z. Bao et al.

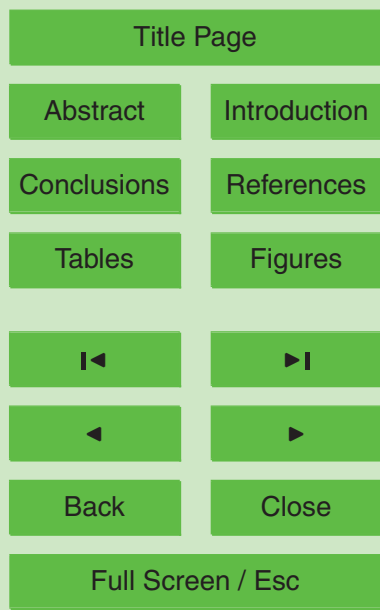

Printer-friendly Version

Interactive Discussion 
largest catchment is Luoduxi catchment with an area of $38064 \mathrm{~km}^{2}$, but the smallest one is only $2582 \mathrm{~km}^{2}$ in Nancha catchment. These catchments covers a large variation of hydro-climatic conditions: from arid to humid areas, and from cold to hot areas, e.g., the annual precipitation, runoff, and mean temperature varies from 387.6 to $1702.4 \mathrm{~mm}$, 5 from 39.9 to $972.2 \mathrm{~mm}$, and from -2.0 to $21.6^{\circ} \mathrm{C}$, respectively.

The daily streamflow data in the 24 hydrological stations is extracted from the "Hydrological Year Book". Most available streamflow data are more than $20 \mathrm{yr}$. Contemporaneous meteorological data including daily precipitation, mean temperature, maximum temperature and minimum temperature are collected from National Meteorological Administration of China, which applies data quality control before releasing these data.

\subsection{Streamflow simulation}

VIC model is applied for the streamflow simulation in the 24 catchments at a $0.25^{\circ}$ spatial and daily temporal resolution, with two kinds of parameters setting methodologies. One is estimating all six parameters through calibration, called 6 parameters methodology. Another one is estimating three baseflow parameters by physical properties of soil and topography, and the remaining three parameters are calibrated, called 3 parameters methodology. Table 3 summarizes the performance of VIC model for monthly streamflow simulation in the 24 catchments with the two kinds of parameters setting methodologies.

$20 \quad$ No matter for 6 parameters methodology or 3 parameters methodology, VIC model performs better in humid areas than that in arid areas. For example, by 6 parameters methodology, the average Nsc in Yangtze River is 0.92, and 0.77 in Haihe River, but it is only 0.67 in Yellow River. An example of three sub-catchments, Gaoqitou, Taolinkou, and Minhe catchment, located in Yangtze River, Haihe River, and Yellow 25 River, respectively, is illustrated in Fig. 4. The results indicate that, compared to observation, simulated streamflow has best goodness-of-fit in Gaoqitou catchment, followed by Taolinkou catchment, and the worst one is in Minhe catchment.
HESSD

8, 7017-7053, 2011

\section{Estimation of baseflow parameters of variable infiltration capacity model}

Z. Bao et al.

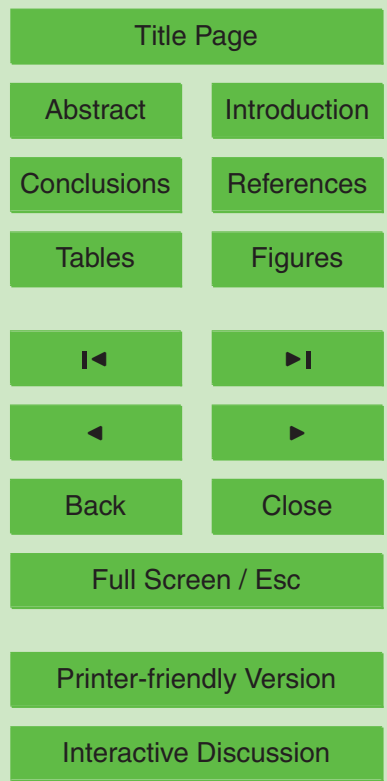


Generally, the 6 parameters methodology has better results than the 3 parameters methodology, but the difference is not significant. The average Mnc values of the 24 catchments are 0.896 and 0.888 by the 6 parameters and 3 parameters methodology, respectively. Meanwhile, there are 15 out of 24 catchments, in which the Mnc value by the 3 parameters methodology is lower than that by the 6 parameters methodology.

\subsection{Sensitivity and uncertainty analysis of model parameters}

The model parameters sensitivity is estimated by MC simulation, and the results in three kinds of hydro-climatic catchments: Gaoqitou, Taolinkou, and Minhe catchment, are illustrated in Fig. 5. Using 6 parameters methodology, (1) the three baseflow parameters and the $d_{3}$-parameter are not sensitive, i.e., the model can perform best within an extensive range of parameters space; (2) $b$-parameter is not sensitive in humid catchment (Fig. 5a), but is sensitive in arid catchment (Fig. 5c); (3) $d_{2}$-parameter is the most sensitive one, with biggest extent in Minhe catchment (Fig. 5c), followed by Taolinkou catchment (Fig. 5b), and then Gaoqitou catchment (Fig. 5a).

15 Using 3 parameters methodology, some original non-sensitive parameters become sensitive. This is because that the equifinality, i.e., the cross-correlation among parameters, is reduced with the reduction of parameters number. For example, in Gaoqitou catchment, $d_{3}$-parameter is not sensitive using 6 parameters methodology, but it becomes sensitive when the 3 parameters methodology is used (Fig. 5a). Meantime, some original sensitive parameters become more sensitive. Therefore, when a threshold of goodness-of-fit is given, the extent of parameters space meeting the conditions in the 3 parameters methodology will be smaller than that in 6 parameters methodology. The general results are summarized in Fig. 6 . That may result in the parameters uncertainty being reduced.

25 Because there are only three parameters needing to be calibrated using 3 parameters methodology, and the $d_{3}$-parameter is not sensitive, the uncertainties of $b$ and $d_{2}$ parameters are analyzed by their variance when the Mnc value is higher than 0.6 (Fig. 7). For $b$-parameter, it is more uncertain in humid areas than that in arid areas.
HESSD

$8,7017-7053,2011$

\section{Estimation of baseflow parameters of variable infiltration capacity model}

Z. Bao et al.

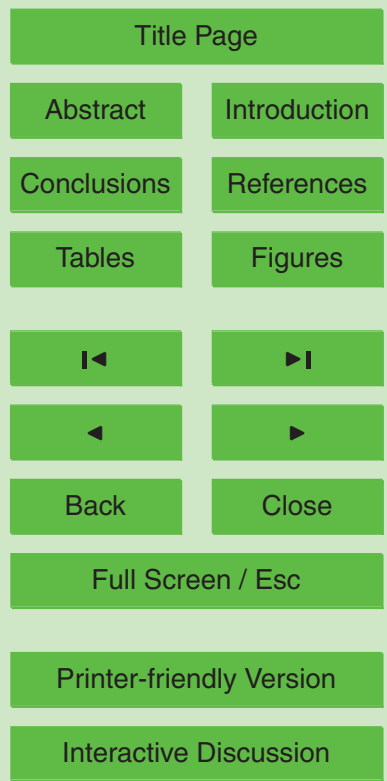


For example, the average variances are 0.070, 0.039, and 0.017 in Yangtze River, Haihe River, and Yellow River, respectively. That are consistent to sensitivity analysis, i.e., if the parameter is more sensitive, the uncertainty will be much lower.

As shown in Fig. 7, the average variances of $b\left(d_{2}\right)$ parameter are $0.052(0.108)$ 5 and $0.050(0.106)$ in the 6 parameters methodology and 3 parameters methodology, respectively. There are $18(16)$ out of 24 catchments, in which the variance of $b\left(d_{2}\right)$ parameters in the 3 parameters methodology is lower than that in the 6 parameters methodology. Overall, the uncertainties of $b$ and $d_{2}$ parameters in the 3 parameters methodology are lower than they in the 6 parameters methodology.

\subsection{Uncertainty estimation of streamflow simulation}

The uncertainty of streamflow simulation are estimated by GLUE methodology, with Mnc higher than 0.6 as a threshold. Using two parameters setting methodology, the $90 \%$ confidence interval and $50 \%$ estimate are illustrated in three catchments: Gaoqitou catchment (Fig. 8), Taolinkou catchment (Fig. 9), and Minhe catchment (Fig. 10). 15 For the three catchments, most of the time, the observations fall within the $90 \%$ confidence interval, except for some peaks in Gaoqitou catchment and some vales in Minhe catchment. The $50 \%$ estimate fits best to observations in Gaoqitou catchment, followed by Taolinkou catchment, and then Minhe catchment. In all the three catchments, the uncertainty, i.e., confidence interval in 3 parameters methodology is lower than that 20 in 6 parameters methodology. For Gaoqitou catchment as an example, the average $90 \%$ confidence interval $\left(Q_{95}-Q_{5}\right)$ is $336.39 \mathrm{~m}^{3} \mathrm{~s}^{-1}$ in 6 parameters methodology, that is higher than $310.11 \mathrm{~m}^{3} \mathrm{~s}^{-1}$ in 3 parameters methodology (Table 4).

In addition, quantitative uncertainty is estimated by probabilistic Shannon Entropy measure, $H$ (Fig. 11). The average $H$ values of the 24 catchments are 8.098 and 8.086 25 in the 6 parameters and 3 parameters methodology, respectively. There are 14 out of 24 catchments, in which $H$ value in 3 parameters methodology is lower than that in 6 parameters methodology. Overall, the uncertainty of streamflow simulation in the 3 parameters methodology is lower than that in the 6 parameters methodology.

7029
HESSD

$8,7017-7053,2011$

\section{Estimation of baseflow parameters of variable infiltration capacity model}

Z. Bao et al.

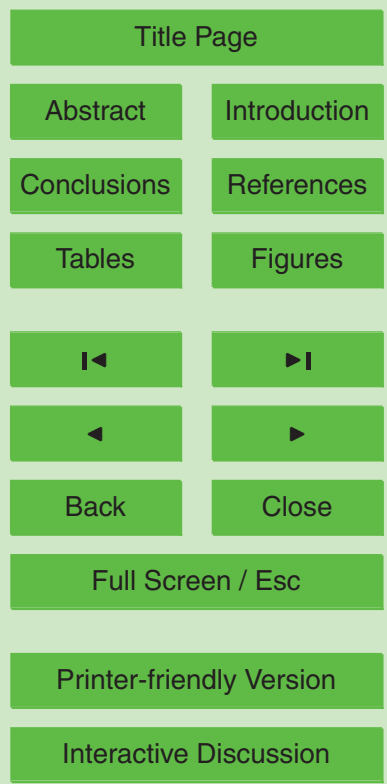

Interactive Discussion 


\section{Summary}

HESSD

By comparing Monte Carlo simulations of the six calibrated parameters of VIC model, the results indicate that the three baseflow parameters are less sensitive than other three parameters, that is consistent to the conclusions of Demaria et al. (2007). There5 fore, the equifinality of the three baseflow parameters is higher than other three parameters. That leads to large uncertainty on transferring parameters in gauged catchments to ungauged catchments for PUB. Although, Huang and Liang (2006) have reduced the baseflow parameters by replacing the original baseflow formulation of VIC model with the concept of kinematic wave and hydrologic similarity, there is still one parameter needing to be calibrated, and we should modify the original programme of VIC model, when their methodology is used. In order to solve this issue, a framework is presented in this study for estimating the three baseflow parameters directly from physical properties of soil and topography. With their physical meanings, the three parameters are estimated by following stages: (1) Based on Darcy's Law, $D_{\mathrm{m}}$-parameter is estimated by saturated hydraulic conductivity and sub-grid average topography slope; (2) $W_{\mathrm{s}}$ parameter is estimated by field capacity and saturated soil moisture; (3) $D_{\mathrm{s}}$-parameter is estimated by Brooks-Corey equation and the variable soil moisture capacity curve.

In addition, the uncertainty of model parameters and streamflow simulation is estimated by the GLUE methodology, under the two kinds of parameters setting methodologies. Although, the original 6 parameters methodology has better results than the 3 parameters methodology, the difference is not significant. When the 3 parameters methodology is used, some original non-sensitive parameters become sensitive and some original sensitive parameters become more sensitive. This is because that the equifinality is reduced with decrease of parameters number. Therefore, when a threshold of goodness-of-fit is given, the extent of parameters space meeting the conditions in the 3 parameters methodology will be smaller than that in 6 parameters methodology. That will result in the parameters uncertainty being reduced. Consequently, the

\section{Estimation of baseflow parameters of variable infiltration capacity model}

Z. Bao et al.

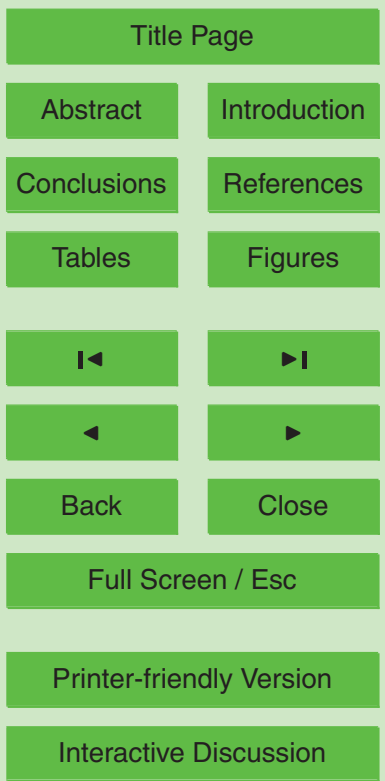


uncertainty of streamflow, i.e., confidence interval and/or Shannon Entropy measure in the 3 parameters methodology will be lower than that in 6 parameters methodology.

Overall, this framework for estimating baseflow parameter could reduce the uncertainty on transferring parameters from gauged catchments to ungauged catchments for 5 PUB, which may be studied as: (1) the three baseflow parameters could be estimated by this framework. (2) $b$-parameter could be estimated using the methodology introduced by Huang et al. (2003). (3) In this case, there are only two parameters $\left(d_{2}\right.$ and $d_{3}$ ) needing to be calibrated with low equifinality. These two parameters may be estimated by regression, spatial proximity, or physical similarity (Oudin et al., 2008; Zhang 10 and Chiew, 2009). The case study should be investigated in the future researches. Meanwhile, this framework could also be extended to other similar models.

Acknowledgements. This research is founded by four research programs: (1) National Basic Research Program of China (grant no. 2010CB951103); (2) International Science \& Technology Cooperation Program of China (grand no. 2010DFA24330); (3) Non-profit Industry Program of 15 the Ministry of Water Resource of China (grant no. 201101015); (4) Non-profit Industry Program of the Ministry of Water Resource of China (grant no. 20110100304).

\section{References}

Abdulla, F. A. and Lettenmaier, D. P.: Development of regional parameter estimation equations for a macroscale hydrologic model, J. Hydrol., 197, 230-257, 1997.

20 Abdulla, F. A., Lettenmaier, D. P., Wood, E. F., and Smith, J. A.: Application of a macroscale hydrologic model to estimate the water balance of Arkansas Red River Basin, J. Geophys. Res., 101(D3), 7449-7459, 1996.

Bárdossy, A.: Calibration of hydrological model parameters for ungauged catchments, Hydrol. Earth Syst. Sci., 11, 703-710, doi:10.5194/hess-11-703-2007, 2007.

25 Beven, K.: A manifesto for the equifinality thesis, J. Hydrol., 320, 18-36, 2006.

Beven, K. J. and Binley, A. M.: The future of distributed model: model calibration and uncertainty prediction, Hydrol. Process., 6, 279-298, 1992.

\section{HESSD}

8, 7017-7053, 2011

\section{Estimation of baseflow parameters of variable infiltration capacity model}

Z. Bao et al.

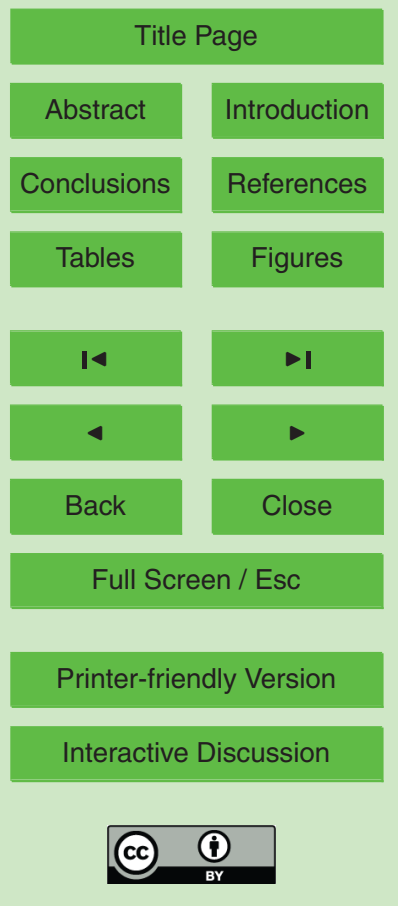


Beven, K. J. and Freer, J.: Equifinality, data assimilation, and uncertainty estimation in mechanistic modeling of complex environmental systems using the GLUE methodology, J. Hydrol., 249, 11-29, 2001.

Blöschl, G. and Sivapalan, M.: Scale issues in hydrological modeling - a review, Hydrol. Process., 9, 251-290, 1995.

Blöschl, G., Ardoin-Bardin, S., Bonell, M., Dorninger, M., Goodrich, D., Gutknecht, D., Matamoros, D., Merz, B., Shand, P., and Szolgay, J.: At what scales do climate variability and land cover change impact on flooding and low flows?, Hydrol. Process., 21, 1241-1247, 2007.

Brooks, R. H. and Corey, A. T.: Hydraulic Properties of Porous Media, Hydrology Papers, Colorado State University, Fort Collins, Colorado, 1964.

Brown, A. E., Zhang, L., McMahon, T. A., Western, A. W., and Vertessy, R. A.: A review of paired catchment studies for determining changes in water yield resulting from alterations in vegetation, J. Hydrol., 310, 28-61, doi:10.1016/j.jhydrol.2004.12.010, 2005.

Campbell, G. S.: A simple method for determining unsaturated conductivity from moisture retention data, Soil Sci., 117(6), 311-314, 1974.

Cosby, B. J., Hornberger, G. M., Clapp, R. B., and Ginn, T. R.: A statistical exploration of the relationships of soil moisture characteristics to the physical properties of soil, Water Resour. Res., 20(6), 682-690, 1984.

Darcy, H.: Les Fontaines Publiques de la Ville de Dijon, Dalmont, Paris, 1856.

Demaria, E. M., Nijssen, B., and Wagener, T.: Monte Carlo sensitivity analysis of land surface parameters using the Variable Infiltration Capacity model, J. Geophys. Res., 112, D11113, doi:10.1029/2006JD007534, 2007.

Foresee, F. D. and Hagan, M. T.: Gauss-Newton Approximation to Bayesian Regularization, International Joint Conference on Neural Networks, Inst. of Electr. and Electron. Eng., Houston, Tex., 1997.

Franchini, M. and Pacciani, M.: Comparative-analysis of several conceptual rainfall runoff models, J. Hydrol., 122, 161-219, 1991.

Gan, T. Y. and Biftu, G. F.: Automatic calibration of conceptual rainfall-runoff models: Optimization algorithms, catchment conditions, and model structure, Water Resour. Res., 32(12), $30 \quad$ 3513-3524, 1996.

Gupta, H. V., Bastidas, L. A., Sorooshian, S., Shuttleworth, W. J., and Yang, Z. L.: Parameter estimation of a land surface scheme using multicriteria methods, J. Geophys. Res., 104, 19491-19503, 1999.

\section{HESSD}

8, 7017-7053, 2011

\section{Estimation of baseflow parameters of variable infiltration capacity model}

Z. Bao et al.

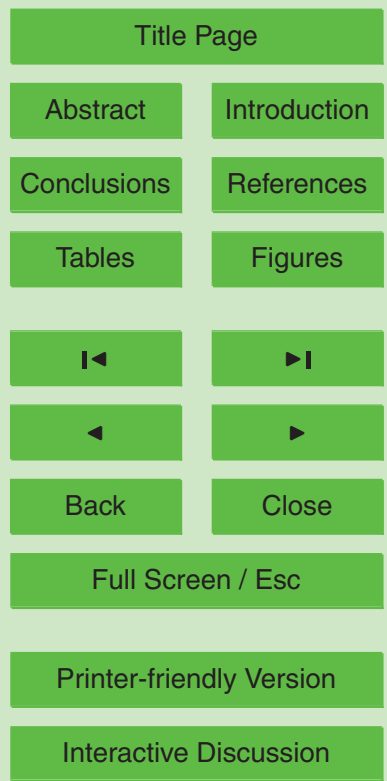


Hornberger, G. M. and Spear, R. C.: An approach to the preliminary analysis of environmental systems, J. Environ. Manage., 12, 7-18, 1981.

Huang, M. and Liang, X.: On the assessment of the impact of reducing parameters and identification of parameter uncertainties for a hydrologic model with applications to ungauged gasins, J. Hydrol., 320, 37-61, 2006.

Huang, M., Liang, X., and Liang, Y.: A transferability study of model parameters for the variable infiltration capacity land surface scheme, J. Geophys. Res., 108(D22), 8864, doi:10.1029/2003JD003676, 2003.

Hundecha, Y., Zehe, E., and Bárdossy, A.: Regional parameter estimation from catchment properties prediction in ungauged basins, Proceedings of the PUB Kick-off meeting held in Brasilia, IAHS Publ., 309, 22-29, 2007.

Hunter, N. M., Bates, P. D., Horritt, M. S., De Roo, A. P. J., and Werner, M. G. F.: Utility of different data types for calibrating flood inundation models within a GLUE framework, Hydrol. Earth Syst. Sci., 9, 412-430, doi:10.5194/hess-9-412-2005, 2005.

15 Jarboe, J. E. and Haan, C. T.: Calibrating a water yield model for small ungauged watersheds, Water Resour. Res., 10, 256-262, 1974.

Juston, J., Seibert, J., and Johansson, P. O.: Temporal sampling strategies and uncertainty in calibrating a conceptual hydrological model for a small boreal catchment, Hydrol. Process., 23, 3093-3109, 2009.

20 Kay, A. L., Jones, D. A., Crooks, S. M., Calver, A., and Reynard, N. S.: A comparison of three approaches to spatial generalization of rainfall-runoff models, Hydrol. Process., 20, 39533973, 2006.

Khu, S.-T. and Werner, M. G. F.: Reduction of Monte-Carlo simulation runs for uncertainty estimation in hydrological modelling, Hydrol. Earth Syst. Sci., 7, 680-692, doi:10.5194/hess7-680-2003, 2003.

Klir, G. J. and Folger, T. A.: Fuzzy Sets, Uncertainty and Information, Prentice Hall, Englewood Cliffs, 1988.

Kohonen, T:: Seif-Organization and Associative Memory, 3rd edition, Springer-Verlag, New York, 312 pp., 1989.

30 Liang, X. and Xie, Z. H.: A new surface runoff parameterization with subgrid-scale soil heterogeneity for land surface models, Adv. Water Resour., 24, 1173-1193, 2001.

\section{HESSD}

$8,7017-7053,2011$

\section{Estimation of baseflow parameters of variable infiltration capacity model}

Z. Bao et al.

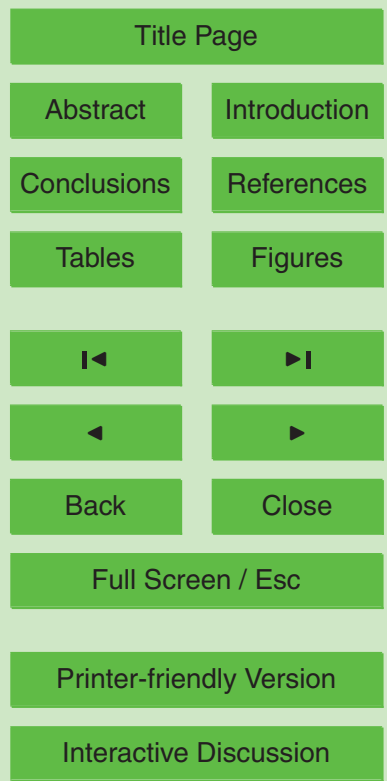


Liang, X., Lettenmaier, D. P., Wood, E. F., and Burges, S. J.: A simple hydrologically based model of land surface water and energy fluxes for general circulation models, J. Geophys. Res., 99, 14415-14428, 1994.

Liang, X., Wood, E. F., and Lettenmaier, D. P.: Surface soil moisture parameterization of the 5 VIC-2L model: evaluation and modification, Global Planet. Change, 13, 195-206, 1996.

Lohmann, D., Raschke, E., Nijssen, B., and Lettenmaier, D. P.: Regional scale hydrology: II. Application of the VIC-2L model to the Weser River, Germany, Hydrolog. Sci. J., 43(1), 143-158, 1998.

Lubès-Niel, H., Paturel, J. E., and Servat, E.: Study of parameter stability of a lumped hydrologic model in a context of climatic variability, J. Hydrol., 278, 213-230, 2003.

Mackay, D. J. C.: Bayesian interpolation, Neural Comput., 4(3), 415-447, 1992.

MacQueen, J.: Some methods for classification and analysis of multivariate observations, in: Proceedings of the Fifth Berkeley Symposium on Mathematical Statistics and Probability, Statistics, 1, 281-297, Univ. of Calif. Press, Berkeley, 1967.

15 Maidment, D. R.: Handbook of Hydrology, R. R. Donnelley \& Sons Company, USA, 1993.

Mclntyre, N., Lee, H., Wheater, H., Young, A., and Wagener, T.: Ensemble predictions of runoff in ungauged catchments, Water Resour. Res., 41, W12434, doi:10.1029/2005WR004289, 2005.

Merz, R. and Blöschl, G.: Regionalisation of catchment model parameters, J. Hydrol., 287, 95-123, 2004.

Merz, R., Parajka, J., and Blöschl, G.: Time stability of catchment model parameters: implications for climate impact analyses, Water Resour. Res., 47, W02531, doi:10.1029/2010WR009505, 2011.

Montanari, A.: Large sample behaviors of the generalized likelihood uncertainty estimation (GLUE) in assessing the uncertainty of rainfall-runoff simulations, Water Resour. Res., 41, W08406, doi:10.1029/2004WR003826, 2005.

Morse, B. S. and Pohll, G.: Stochastic capture zone analysis of an arsenic-contaminated well using the generalized likelihood uncertainty estimator (GLUE) methodology, Water Resour. Res., 39(6), 1151, doi:10.1029/2002WR001470, 2003.

30 Oudin, L., Andréassian, V., Perrin, C., Michel, C., Moine, N. L.: Spatial proximity, physical similarity, regression and ungaged catchments: a comparison of regionalization approaches based on 913 French catchments, Water Resour. Res., 44, W03413, doi:10.1029/2007WR006240, 2008.
HESSD

$8,7017-7053,2011$

\section{Estimation of baseflow parameters of variable infiltration capacity model}

Z. Bao et al.

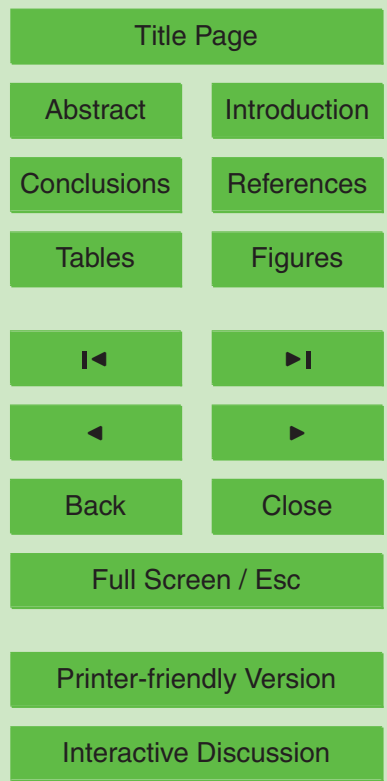


Parajka, J., Merz, R., and Blöschl, G.: A comparison of regionalisation methods for catchment model parameters, Hydrol. Earth Syst. Sci., 9, 157-171, doi:10.5194/hess-9-157-2005, 2005.

Parajka, J., Blöschl, G., and Merz, R.: Regional calibration of catchment models: Potential for ungauged catchments, Water Resour. Res., 43, W06406, doi:10.1029/2006WR005271, 2007.

Rawls, W. J., Gimenez, D., and Grossman, R.: Use of soil texture, bulk density, and slope of the water retention curve to predict saturated hydraulic conductivity, T. ASAE, 41(4), 983-988, 1998.

10 Rojas, R., Batelaan, O., Feyen, L., and Dassargues, A.: Assessment of conceptual model uncertainty for the regional aquifer Pampa del Tamarugal - North Chile, Hydrol. Earth Syst. Sci., 14, 171-192, doi:10.5194/hess-14-171-2010, 2010.

Samuel, J. M., Asce, P. C., and Metcalfe, R. A.: Estimation of continuous streamflow in Ontario ungauged basins: Comparison of regionalization methods, J. Hydrol. Eng., 16 (5), 447-459, doi:10.1061/(ASCE)HE.1943-5584.0000338, 2011.

Shi, X., Wood, A. W., and Lettenmaier, D. P.: How essential is hydrologic model calibration to seasonal streamflow forecasting?, J. Hydrometeorol., 9, 1350-1363, doi:10.1175/2008JHM1001.1, 2008.

Sivapalan, M., Takeuchi, K., and Franks, S. W.: IAHS decade on predictions in ungauged basins (PUB), 2003-2012: shaping an exciting future for the hydrological sciences, Hydrolog. Sci. J., 48(6), 857-880, 2003.

Spear, R. C. and Hornberger, G. M.: Eutrophication in Peel Inlet. II. Identification of critical uncertainties via generalized sensitivity analysis, Water Res., 14, 43-49, doi:10.1016/00431354(80)90040-8, 1980.

Stedinger, J. R., Vogel, R. M., Lee, S. U., and Batchelder, R.: Appraisal of the generalized likelihood uncertainty estimation (GLUE) method, Water Resour. Res., 44, W00B06, doi:10.1029/2008WR006822, 2008.

Su, F. G., Adam, J. C., Bowling, L. C., and Lettenmaier, D. P.: Streamflow simulations of the terrestrial Arctic domain, J. Geophys. Res., 110, D08112, doi:10.1029/2004JD005518, 2005.

30 Todini, E.: The ARNO rainfall-runoff model, J. Hydrol., 175, 339-382, 1996.

Vrugt, J. A., Gupta, H. V., Bouten, W., and Sorooshian, S.: A shuffled complex evolution metropolis algorithm for optimization and uncertainty assessment of hydrologic model parameters, Water Resour. Res., 39(8), 1201, doi:10.1029/2002WR001642, 2003.

\section{HESSD}

8, 7017-7053, 2011

Estimation of baseflow parameters of variable infiltration capacity model

Z. Bao et al.

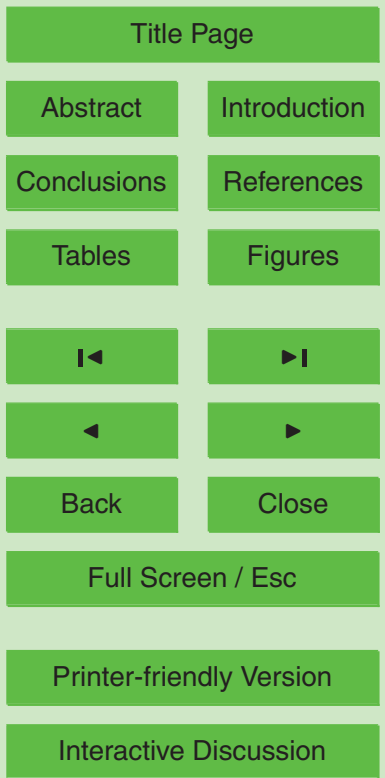


Wagener, T.: Can we model the hydrological impacts of environmental change?, Hydrol. Process., 21, 3233-3236, doi:10.1002/hyp.6873, 2007.

Wagener, T., Mclntyre, N., Lees, M. J., Wheater, H. S., and Gupta, H. V.: Towards reduced uncertainty in conceptual rainfall-runoff modeling: dynamic identifiability analysis, Hydrol. Process., 17, 455-476, 2003.

Wagener, T., Sivapalan, M., Troch, P. A., McGlynn, B. L., Harman, C. J., Gupta, H. V., Kumar, P., Rao, P. S. C., Basu, N. B., and Wilson, J. S.: The future of hydrology: An evolving science for a changing world, Water Resour. Res., 46, W05301, doi:10.1029/2009WR008906, 2010.

Weeks, W. D. and Ashkenasy, N. M.: Regional parameters for the Sacramento model: a case study, Civ. Eng. Trans. Inst. Eng. Aust, CE27, 305-313, 1985.

Weeks, W. D. and Boughton, W. C.: A simple ARMA hydrologic model for ungauged catchments in Queensland, Civ. Eng. Trans. Inst. Eng. Aust, CE29, 85-95, 1987.

Wood, E. F., Lettenmaier, D. P., Liang, X., Lohmann, D., Boone, A., Chang, S., Chen, F., Dai, Y., Dickinson, R. E., Duan, Q., Ek, M., Gusev, Y. M., Habets, F., Irannejad, P., Koster, R., Mitchel, K. E., Nasonova, O. N., Noilhan, J., Schaake, J., Schlosser, A., Shao, Y., Shmakin, A. B., Verseghy, D., Warrach, K., Wetzel, P., Xue, Y., Yang, Z., and Zeng, Q.: The Project for Intercomparision of Land-Surface Parameterization Schemes (PILPS) phase 2(c) Red-Arkansas River Basin Experiment: 1. Experiment description and summary intercomparisions, Global Planet. Change, 19, 115-135, 1998.

Young, A. R.: Stream flow simulation within UK ungauged catchments using a daily rainfallrunoff model, J. Hydrol., 320, 155-172, 2006.

Zhang, Y. and Chiew, H. S.: Relative merits of different methods for runoff predictions in ungauged catchments, Water Resour. Res., 45, W07412, doi:10.1029/2008WR007504, 2009.

Zhao, R. J.: The Xinanjiang model applied in China, J. Hydrol., 135, 371-381, 1992.

Zhao, R., Zhang, Y., Fang, L., Liu, X., and Zhang, Q.: The Xinanjiang Model, Hydrological Forecasting Proceedings Oxford Symposium, IAHS Publ., 129, 351-356, 1980.

Zheng, Y. and Keller, A. A.: Uncertainty assessment in watershed-scale water quality modeling and management: 1. Framework and application of generalized likelihood uncertainty estimation (GLUE) approach, Water Resour. Res., 43, W08407, doi:10.1029/2006WR005345, $30 \quad 2007$.

Zhu, C. M. and Lettenmaier, D. P.: Long-term climate and derived surface hydrology and energy flux data for Mexico: 1925-2004, J. Climate, 20(9), 1936-1946, 2007.
HESSD

$8,7017-7053,2011$

\section{Estimation of baseflow parameters of variable infiltration capacity model}

Z. Bao et al.

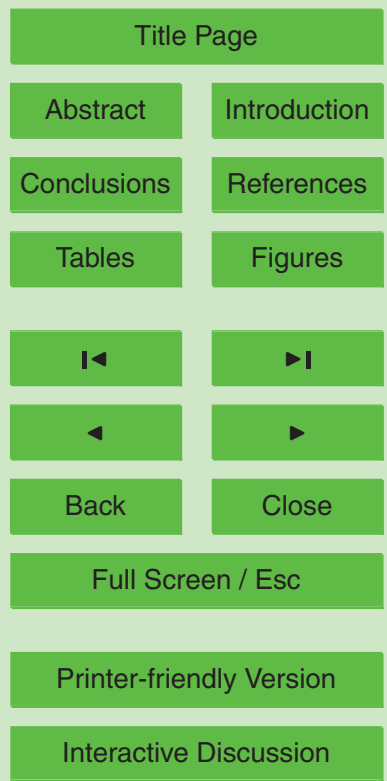




\section{HESSD}

8, 7017-7053, 2011

\section{Estimation of baseflow parameters of variable infiltration capacity model}

Table 1. Six parameters of VIC model for calibration and uncertainty analysis.

Z. Bao et al.

\begin{tabular}{|c|c|c|}
\hline Parameter & Unit & Description \\
\hline$W_{\mathrm{s}}$ & $\mathrm{N} / \mathrm{A}$ & $\begin{array}{l}\text { Fraction of the maximum soil moisture of the third soil layer where } \\
\text { non-linear baseflow occurs }\end{array}$ \\
\hline$D_{\mathrm{s}}$ & $\mathrm{N} / \mathrm{A}$ & Fraction of $D_{\mathrm{m}}$ where non-linear baseflow begins \\
\hline$D_{\mathrm{m}}$ & $\mathrm{mm}_{\text {day }}{ }^{-1}$ & Maximum baseflow that can occur from the third soil layer \\
\hline$b$ & $\mathrm{~N} / \mathrm{A}$ & Defining the shape of the variable soil moisture capacity curve \\
\hline$d_{2}$ & $\mathrm{~m}$ & Soil depth of the second soil layer \\
\hline$d_{3}$ & $\mathrm{~m}$ & Soil depth of the third soil layer \\
\hline
\end{tabular}




\section{HESSD}

$8,7017-7053,2011$

Table 2. Basic information of the 24 sub-catchments.

\begin{tabular}{|c|c|c|c|c|c|c|c|c|c|}
\hline No. & Hydro-station & Major basin & Lon. $\left(\mathrm{E}^{\circ}\right)$ & Lat. $\left(\mathrm{N}^{\circ}\right)$ & Area $\left(\mathrm{km}^{2}\right)$ & $P(\mathrm{~mm})$ & $R(\mathrm{~mm})$ & $T\left({ }^{\circ} \mathrm{C}\right)$ & $R_{\mathrm{c}}$ \\
\hline 1 & Xiaoergou & Songhuajiang River & 123.72 & 49.20 & 16761 & 480.46 & 195.72 & -2.01 & 0.41 \\
\hline 2 & Chaersen & Songhuajiang River & 121.90 & 46.32 & 7827 & 447.57 & 88.60 & 0.19 & 0.20 \\
\hline 3 & Wuchang & Songhuajiang River & 127.10 & 44.87 & 5642 & 672.45 & 252.31 & 3.20 & 0.38 \\
\hline 4 & Nancha & Songhuajiang River & 129.25 & 47.13 & 2582 & 610.12 & 314.63 & 0.13 & 0.52 \\
\hline 5 & Xiaolinzi & Liaohe River & 122.90 & 41.35 & 10254 & 808.27 & 221.99 & 7.05 & 0.27 \\
\hline 6 & Taolinkou & Haihe River & 119.05 & 40.13 & 5060 & 650.00 & 142.00 & 7.38 & 0.22 \\
\hline 7 & Zhangjiafen & Haihe River & 116.78 & 40.62 & 8506 & 453.60 & 64.40 & 9.12 & 0.14 \\
\hline 8 & Weishui & Haihe River & 114.13 & 38.03 & 5387 & 610.60 & 131.90 & 9.72 & 0.22 \\
\hline 9 & Minhe & Yellow River & 102.80 & 36.33 & 15342 & 443.30 & 123.60 & 1.80 & 0.28 \\
\hline 10 & Wenjiachuan & Yellow River & 110.75 & 38.48 & 8515 & 387.56 & 72.00 & 7.41 & 0.19 \\
\hline 11 & Daning & Yellow River & 110.72 & 36.47 & 3992 & 512.96 & 39.90 & 8.49 & 0.08 \\
\hline 12 & Qinan & Yellow River & 105.67 & 34.90 & 9805 & 454.95 & 41.97 & 6.82 & 0.09 \\
\hline 13 & Longmenzhen & Yellow River & 112.47 & 34.55 & 5318 & 736.31 & 245.92 & 12.37 & 0.33 \\
\hline 14 & Xixian & Huaihe River & 114.73 & 32.33 & 10190 & 1093.60 & 403.00 & 14.90 & 0.37 \\
\hline 15 & Linyi & Huaihe River & 118.40 & 35.02 & 10315 & 868.60 & 363.20 & 12.50 & 0.42 \\
\hline 16 & Dengyingyan & Yangtze River & 104.73 & 29.90 & 14484 & 987.43 & 672.87 & 15.75 & 0.68 \\
\hline 17 & Luoduxi & Yangtze River & 106.58 & 30.33 & 38064 & 1134.20 & 575.82 & 15.08 & 0.51 \\
\hline 18 & Gaoqitou & Yangtze River & 110.35 & 28.62 & 17698 & 1386.00 & 791.70 & 14.71 & 0.57 \\
\hline 19 & Laobutou & Yangtze River & 111.60 & 26.27 & 21341 & 1532.83 & 972.15 & 17.06 & 0.63 \\
\hline 20 & Xiangjiaping & Yangtze River & 106.28 & 32.85 & 6448 & 775.48 & 305.97 & 10.29 & 0.39 \\
\hline 21 & Lijiadu & Yangtze River & 116.17 & 28.22 & 15811 & 1702.43 & 810.77 & 17.88 & 0.48 \\
\hline 22 & Lanxi & Southeast rivers & 119.47 & 29.22 & 18233 & 1581.70 & 891.80 & 17.14 & 0.56 \\
\hline 23 & Sancha & Pearl River & 108.95 & 24.47 & 16280 & 1447.60 & 768.10 & 19.38 & 0.53 \\
\hline 24 & Jinji & Pearl River & 110.82 & 23.23 & 9103 & 1629.80 & 779.40 & 21.56 & 0.48 \\
\hline
\end{tabular}

$P$ means average annual precipitation; $R$ means average annual runoff depth; $T$ means average annual mean temperature; $R_{\mathrm{c}}$ means average annual runoff coefficient.

\section{Estimation of baseflow parameters of variable infiltration capacity model}

Z. Bao et al.

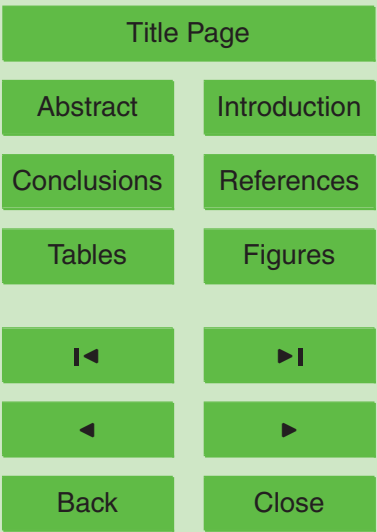

Full Screen / Esc

Printer-friendly Version

Interactive Discussion 
Table 3. Performance of VIC model in the 24 catchments using two kinds of parameters setting methodologies.

\begin{tabular}{|c|c|c|c|c|c|c|c|}
\hline \multirow{2}{*}{ No. } & \multirow{2}{*}{ Catchment } & \multicolumn{3}{|c|}{6 parameters } & \multicolumn{3}{|c|}{3 parameters } \\
\hline & & Nsc & $\operatorname{Re}(\%)$ & Mnc & Nsc & $\operatorname{Re}(\%)$ & Mnc \\
\hline 1 & Xiaoergou & 0.719 & -0.141 & 0.859 & 0.704 & 2.943 & 0.837 \\
\hline 2 & Chaersen & 0.710 & 0.543 & 0.852 & 0.708 & 0.648 & 0.851 \\
\hline 3 & Wuchang & 0.735 & -2.524 & 0.855 & 0.745 & 4.454 & 0.850 \\
\hline 4 & Nancha & 0.846 & -0.223 & 0.922 & 0.840 & 4.707 & 0.896 \\
\hline 5 & Xiaolinzi & 0.835 & 1.001 & 0.912 & 0.798 & 4.530 & 0.876 \\
\hline 6 & Taolinkou & 0.816 & -1.187 & 0.902 & 0.801 & 3.503 & 0.883 \\
\hline 7 & Zhangjiafen & 0.748 & -1.691 & 0.866 & 0.746 & -2.270 & 0.862 \\
\hline 8 & Weishui & 0.740 & -1.321 & 0.863 & 0.748 & 1.359 & 0.867 \\
\hline 9 & Minhe & 0.697 & -0.857 & 0.844 & 0.727 & -2.256 & 0.852 \\
\hline 10 & Wenjiachuan & 0.631 & -9.523 & 0.768 & 0.577 & -8.699 & 0.745 \\
\hline 11 & Daning & 0.647 & -0.815 & 0.819 & 0.644 & 0.082 & 0.822 \\
\hline 12 & Qinan & 0.683 & 0.422 & 0.839 & 0.683 & 0.388 & 0.840 \\
\hline 13 & Longmenzhen & 0.686 & -1.087 & 0.838 & 0.703 & -1.111 & 0.846 \\
\hline 14 & Xixian & 0.786 & -2.867 & 0.879 & 0.780 & 3.319 & 0.875 \\
\hline 15 & Linyi & 0.885 & 0.003 & 0.942 & 0.826 & -0.558 & 0.910 \\
\hline 16 & Dengyingyan & 0.899 & 0.011 & 0.949 & 0.870 & -2.768 & 0.921 \\
\hline 17 & Luoduxi & 0.927 & 1.495 & 0.956 & 0.921 & 2.376 & 0.949 \\
\hline 18 & Gaoqitou & 0.928 & 0.529 & 0.961 & 0.926 & 0.525 & 0.960 \\
\hline 19 & Laobutou & 0.917 & 1.440 & 0.951 & 0.918 & 0.008 & 0.959 \\
\hline 20 & Xiangjiaping & 0.920 & -1.520 & 0.952 & 0.910 & -0.619 & 0.951 \\
\hline 21 & Lijiadu & 0.941 & -0.018 & 0.970 & 0.937 & 1.317 & 0.962 \\
\hline 22 & Lanxi & 0.937 & 0.498 & 0.966 & 0.942 & -0.255 & 0.970 \\
\hline 23 & Sancha & 0.871 & -0.457 & 0.933 & 0.880 & 0.365 & 0.936 \\
\hline 24 & Jinji & 0.812 & -0.777 & 0.902 & 0.822 & -1.880 & 0.902 \\
\hline
\end{tabular}

\section{HESSD}

8, 7017-7053, 2011

Estimation of baseflow parameters of variable infiltration capacity model

Z. Bao et al.

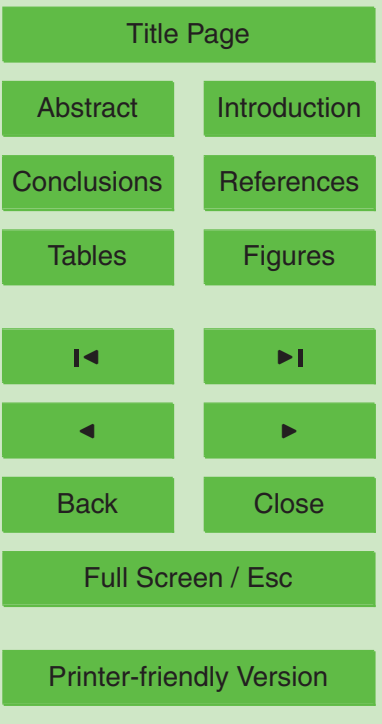

Interactive Discussion 


\section{HESSD}

8, 7017-7053, 2011

\section{Estimation of baseflow parameters of variable infiltration capacity model}

Z. Bao et al.

Table 4. The average confidence interval $\left(Q_{95}-Q_{5}\right)$ for simulated streamflow in Gaoqitou, Taolinkou, and Minhe catchment by two kinds of parameters setting methodologies.

\begin{tabular}{lccc}
\hline Interval $\left(\mathrm{m}^{3} \mathrm{~s}^{-1}\right)$ & Gaoqitou catchment & Taolinkou catchment & Minhe catchment \\
\hline 6 parameters & 336.39 & 35.13 & 43.94 \\
3 parameters & 310.11 & 29.54 & 40.43 \\
\hline
\end{tabular}

Title Page

Abstract Introduction

Conclusions References

Tables Figures

14

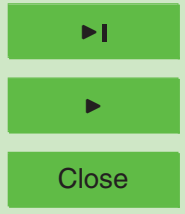

Back

Full Screen / Esc

Printer-friendly Version

Interactive Discussion 


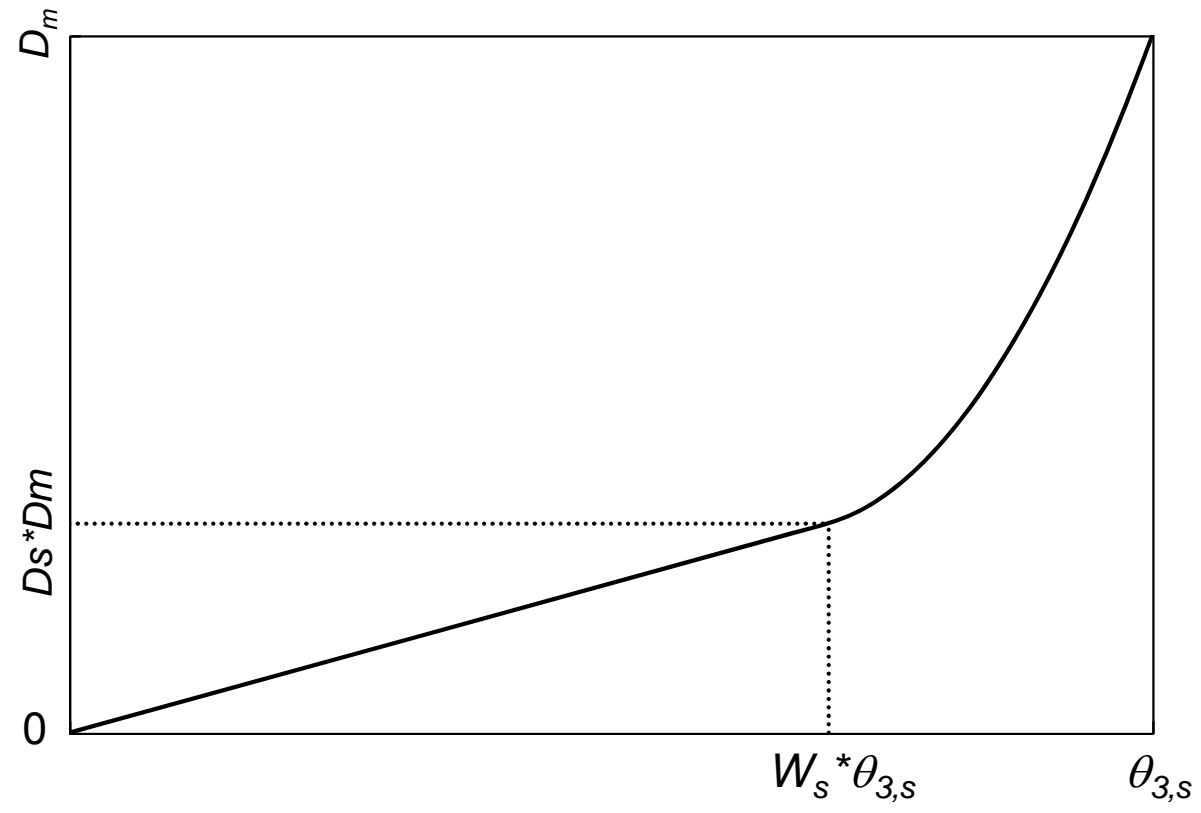

\section{HESSD}

8, 7017-7053, 2011

\section{Estimation of} baseflow parameters of variable infiltration capacity model

Z. Bao et al.

Title Page

Abstract

Conclusions

Tables

14

4

Back

Full Screen / Esc

Printer-friendly Version

Interactive Discussion 


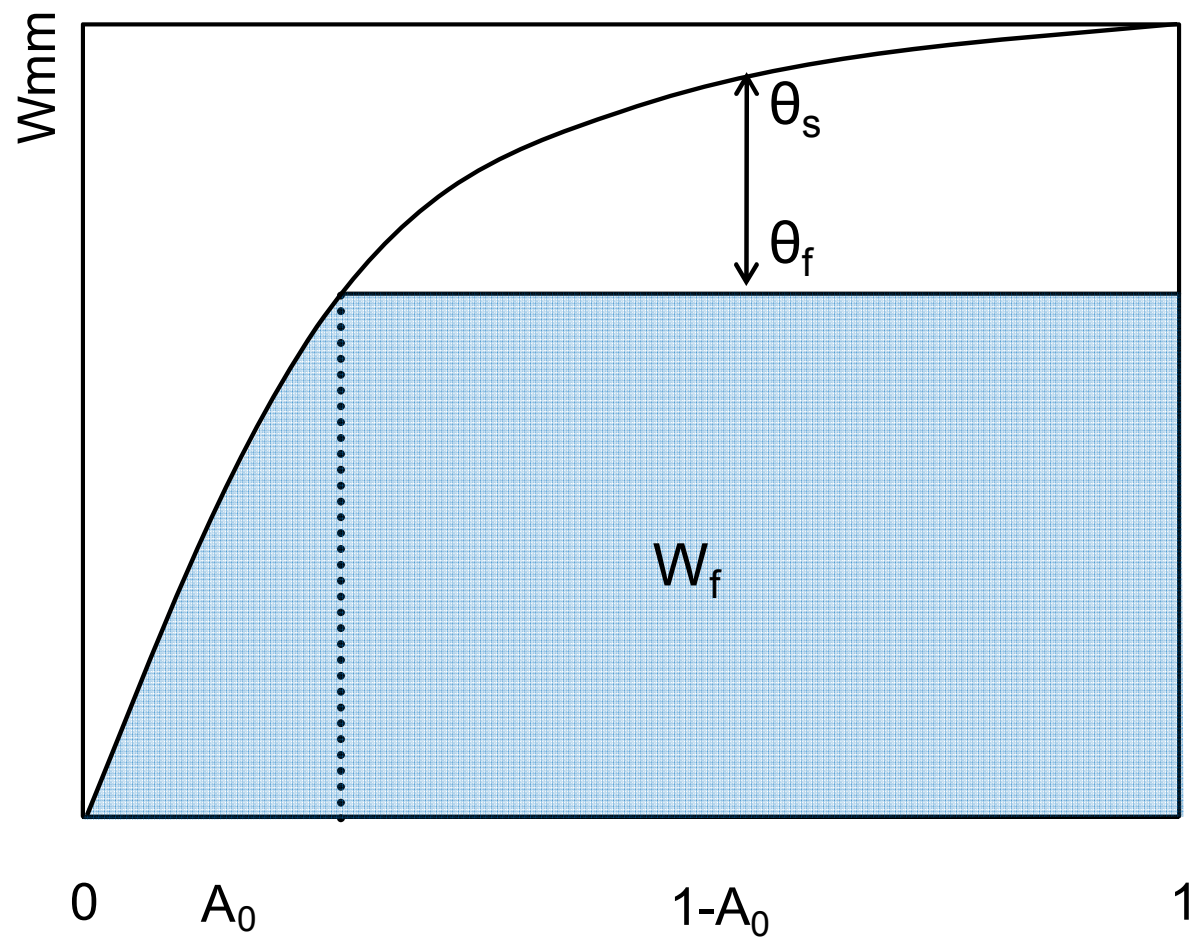

Fig. 2. Schematic representation of soil moisture capacity distribution and estimation of $D_{\mathrm{s}}$ parameter. The grey area represents the field capacity, $W_{\mathrm{f}}$, of a sub-grid. Then $\theta_{\mathrm{f}}$ could be calculated by the variable soil moisture capacity curve. $\theta_{\mathrm{s}}$ means point saturated soil moisture. See details in Sect. 3.

\section{HESSD}

8, 7017-7053, 2011

\section{Estimation of baseflow parameters of variable infiltration capacity model}

Z. Bao et al.

\section{Title Page}

\section{Abstract}

Introduction

Conclusions

References

Tables

Figures

14

4

Back

\section{Full Screen / Esc}

Printer-friendly Version

Interactive Discussion 


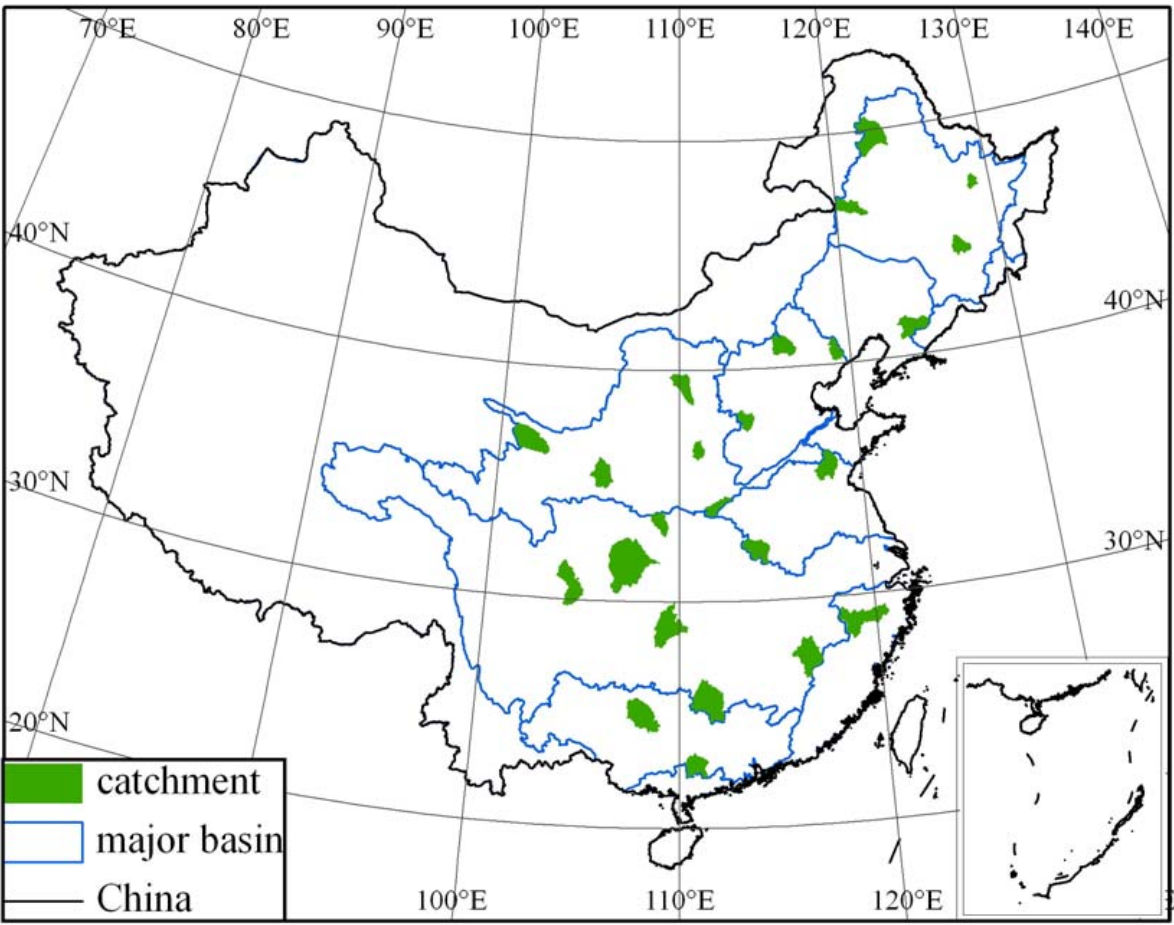

HESSD

8, 7017-7053, 2011

\section{Estimation of baseflow parameters of variable infiltration capacity model \\ Z. Bao et al.}

Title Page

Abstract

Conclusions

Tables

14

4

Back

Introduction

References

Figures

$\rightarrow$

$\checkmark$

Close

Fig. 3. Locations of the 24 sub-catchments in China.

\section{Full Screen / Esc}

Printer-friendly Version

Interactive Discussion 


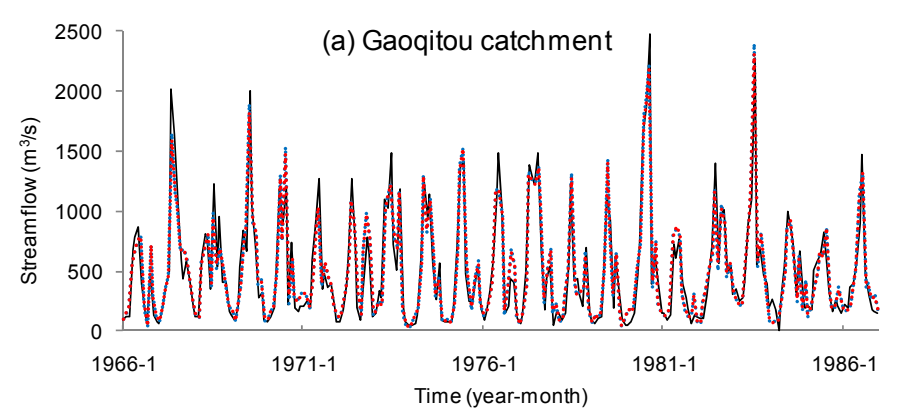

HESSD

8, 7017-7053, 2011
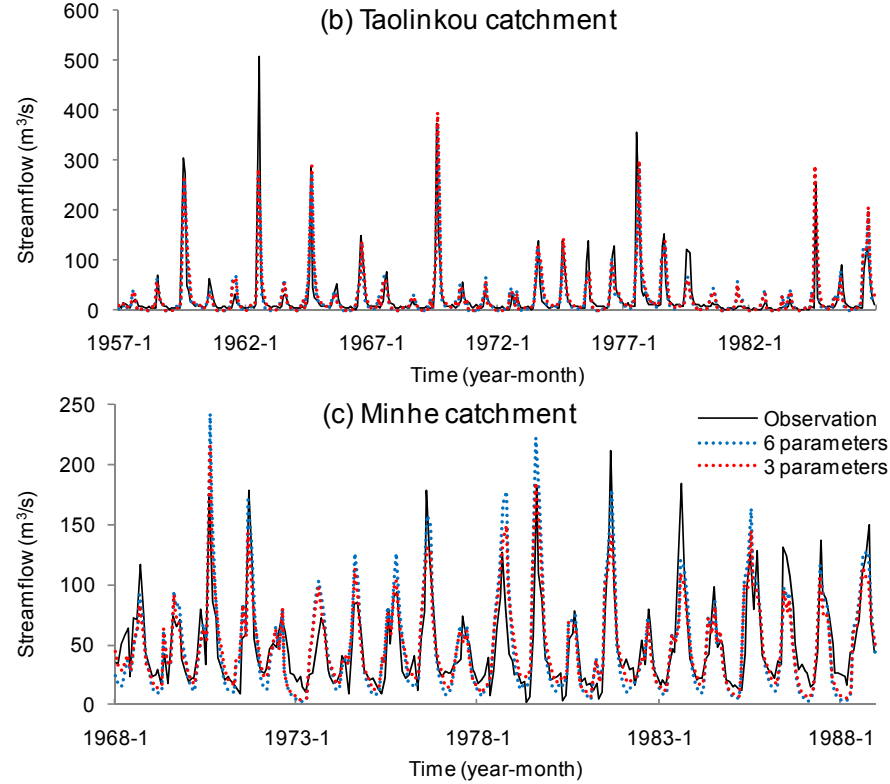

\section{Estimation of baseflow parameters of variable infiltration capacity model}

Z. Bao et al.

Title Page

Abstract Introduction

Conclusions

References

Tables

Figures

14

$\rightarrow$

4

Back

Close

Full Screen / Esc

Printer-friendly Version

Interactive Discussion 

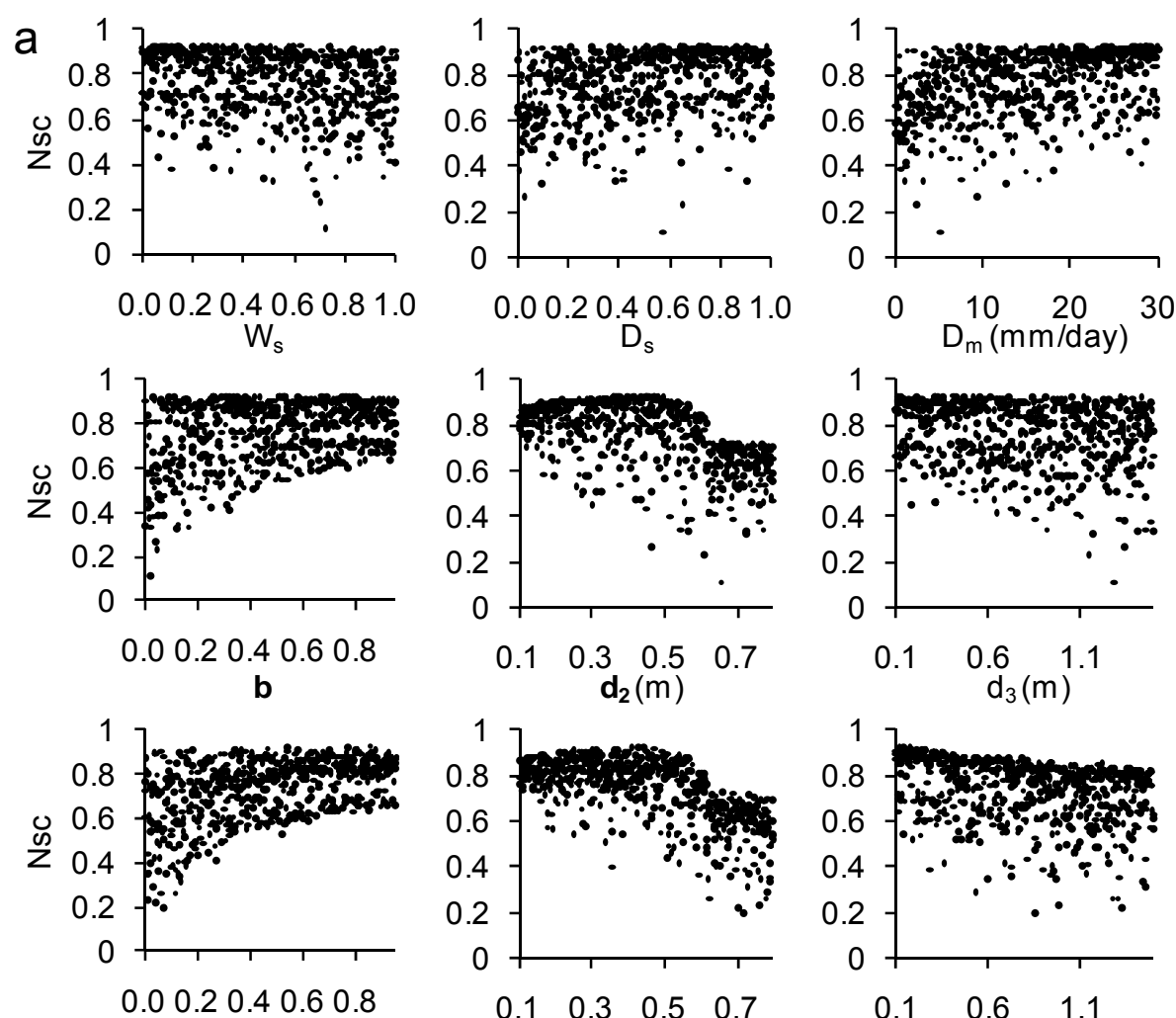

b

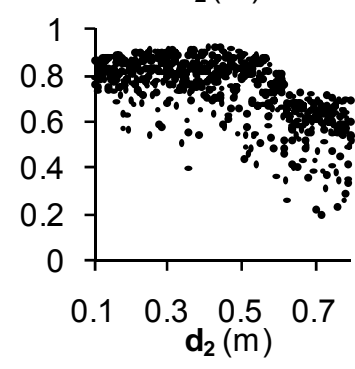

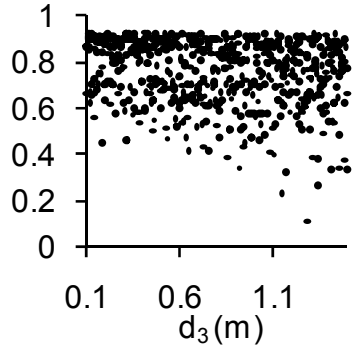

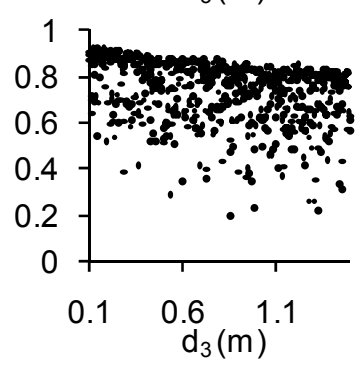

Fig. 5. Scatterplots between model parameters and Nash-Sutcliffe coefficient (Nsc) in three catchments. (a) Gaoqitou catchment (humid), (b) Taolinkou catchment (semi-humid); (c) Minhe catchment (arid). The first 6 figures are under 6 parameters setting methodology, and the last 3 figures are under 3 parameters setting methodology.

\section{HESSD}

8, 7017-7053, 2011

\section{Estimation of baseflow parameters of variable infiltration capacity model \\ Z. Bao et al.}

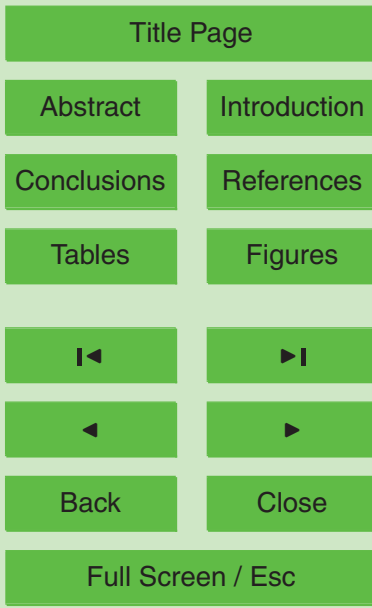

Printer-friendly Version

Interactive Discussion 


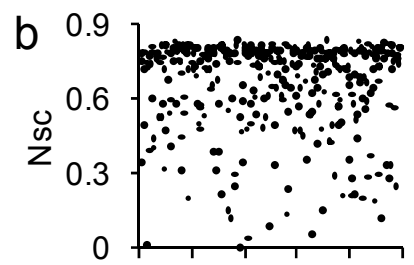

$\begin{array}{lllll}0 & 0.2 & 0.40 .60 .8 & 1\end{array}$

$\mathrm{W}_{\mathrm{s}}$
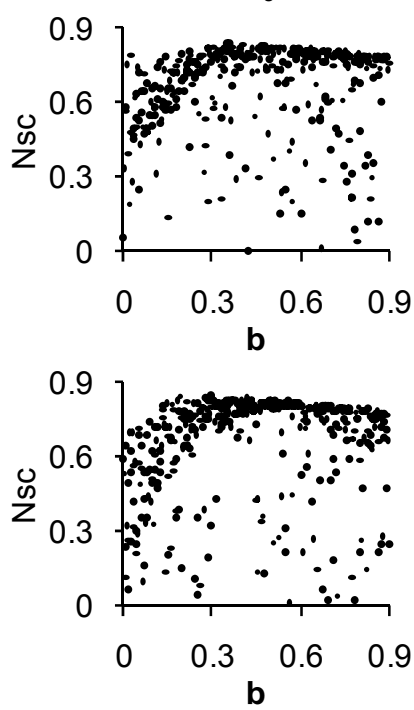

b

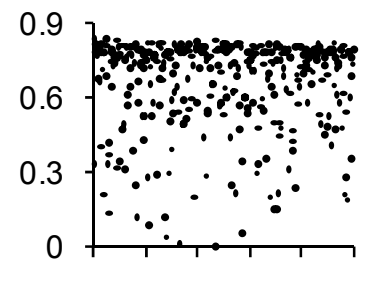

$\begin{array}{lll}0 & 0.20 .40 .60 .8 & 1\end{array}$

$\mathrm{D}_{\mathrm{s}}$
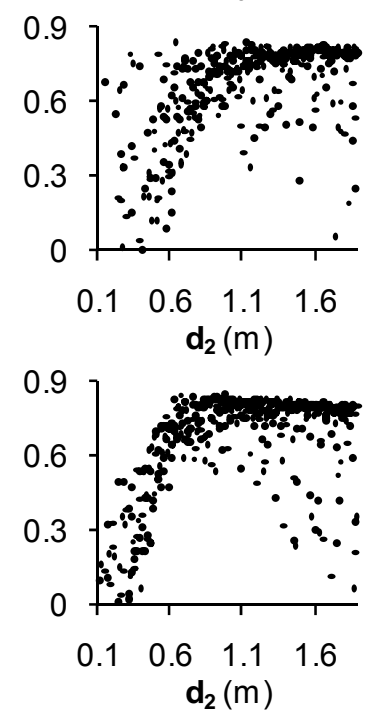
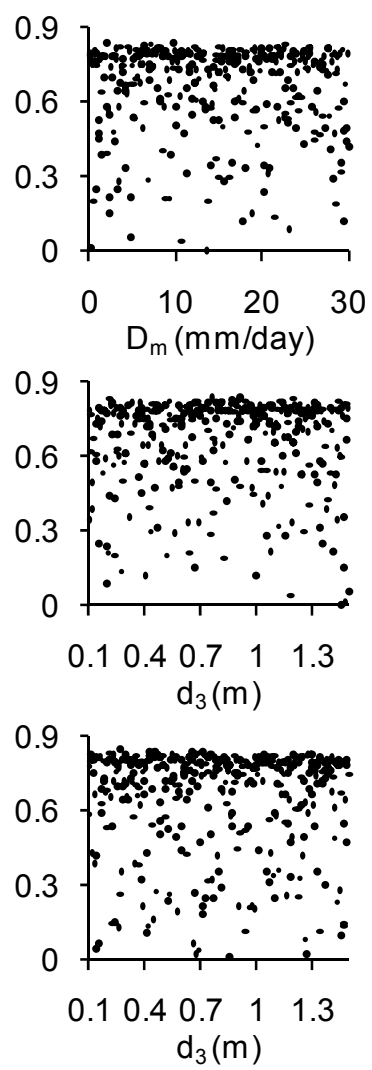

HESSD

8, 7017-7053, 2011

Estimation of baseflow parameters of variable infiltration capacity model

Z. Bao et al.

Title Page

Abstract

Introduction

Conclusions

References

Tables

Figures

I

4

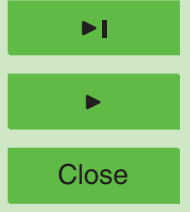

Back

Full Screen / Esc

Printer-friendly Version

Interactive Discussion 


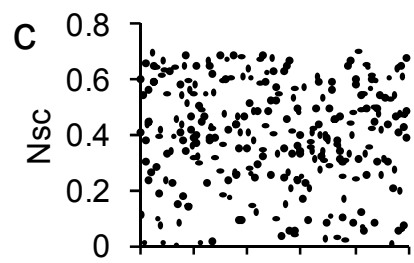

$\begin{array}{llllll}0 & 0.2 & 0.4 & 0.6 & 0.8 & 1\end{array}$ $\mathrm{W}_{\mathrm{s}}$
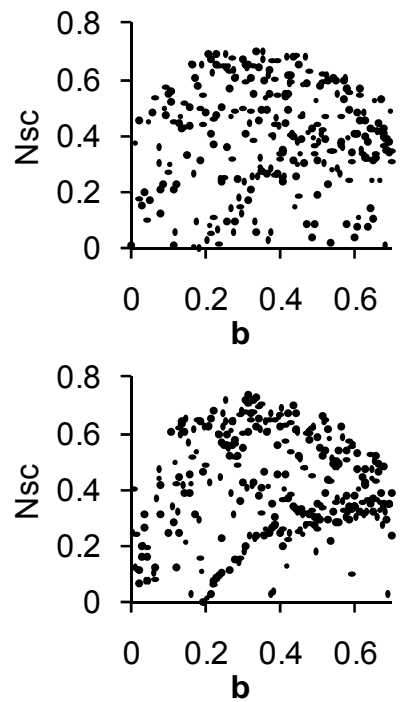

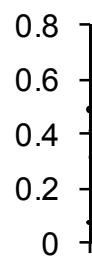

$\begin{array}{llllll}0 & 0.2 & 0.4 & 0.6 & 0.8 & 1\end{array}$ $D_{\mathrm{s}}$
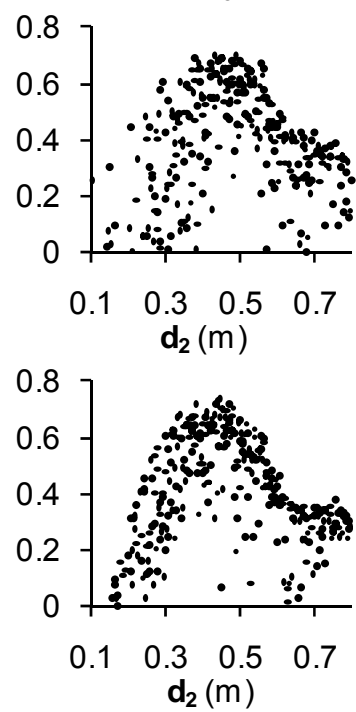
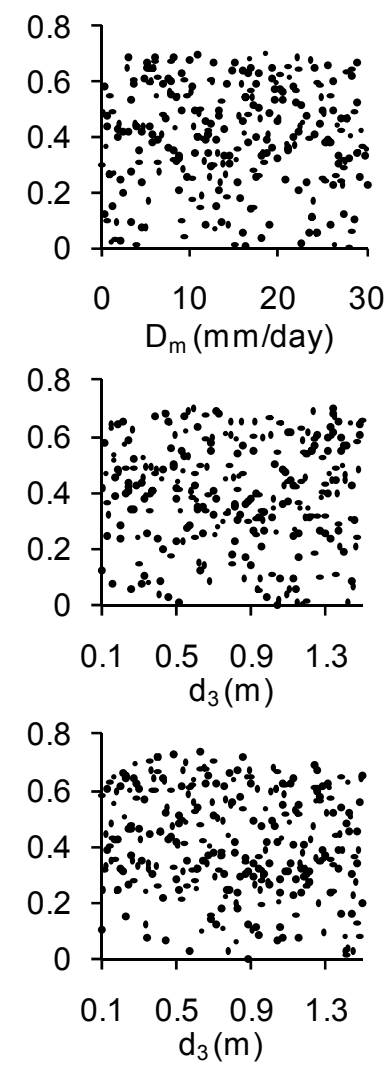

HESSD

8, 7017-7053, 2011

\section{Estimation of baseflow parameters of variable infiltration capacity model}

Z. Bao et al.

Title Page

Abstract

Introduction

Conclusions

References

Tables

Figures
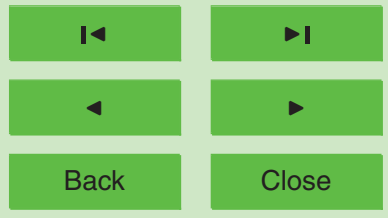

Full Screen / Esc

Printer-friendly Version

Interactive Discussion 


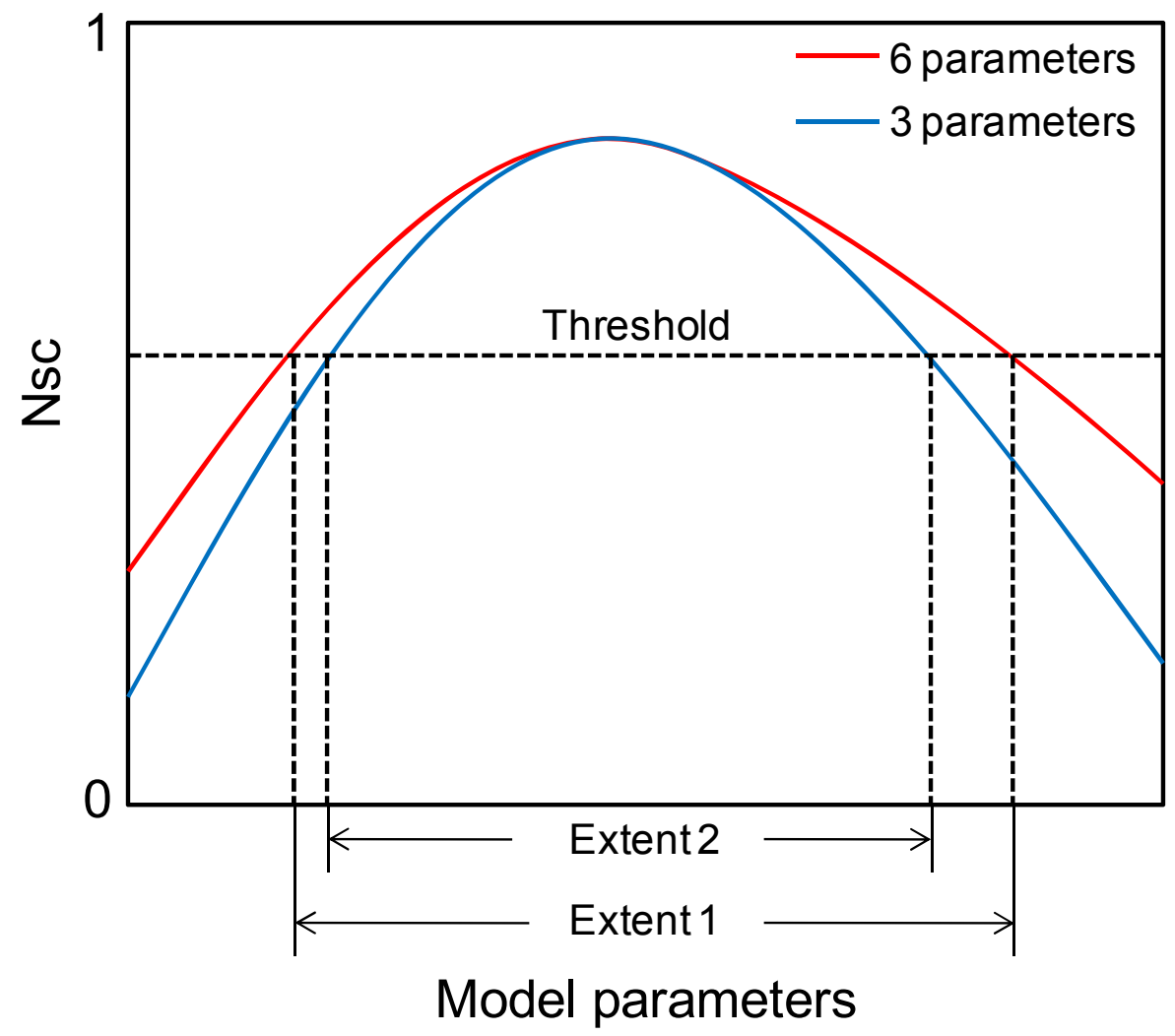

HESSD

8, 7017-7053, 2011

\section{Estimation of baseflow parameters} of variable infiltration capacity model

Z. Bao et al.

Title Page

Abstract

Conclusions

Tables

14

4

Back

Full Screen / Esc

Printer-friendly Version

Interactive Discussion 


\section{HESSD}

8, 7017-7053, 2011

\section{Estimation of baseflow parameters of variable infiltration} capacity model
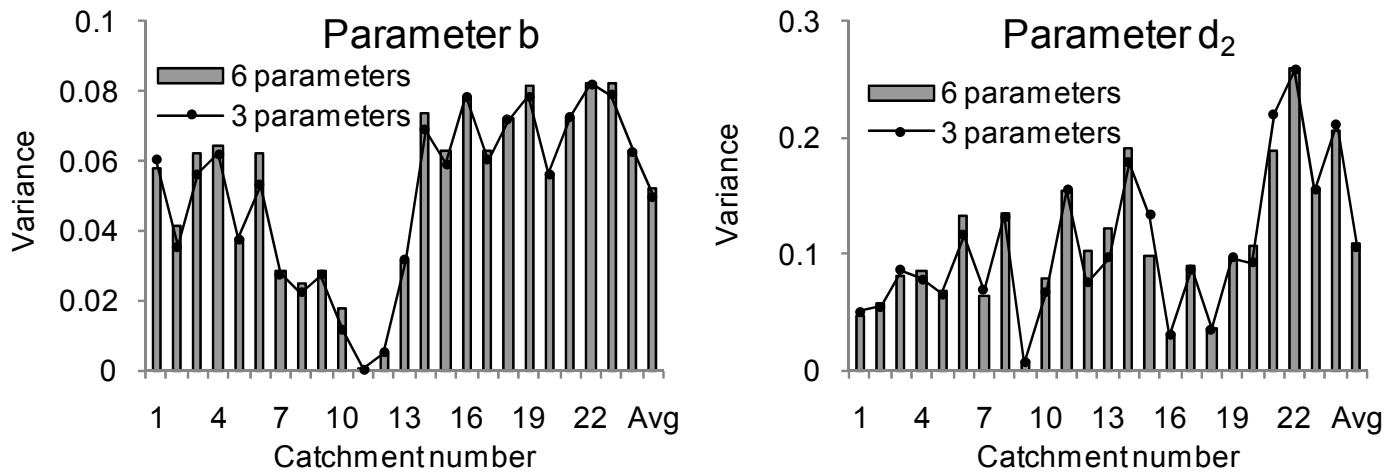

Z. Bao et al.

Fig. 7. Comparison of the variance of parameter $b$ and $d_{2}$ under two kinds of parameters setting methodologies, when Mnc is higher than the threshold.

Title Page

\section{Abstract}

Introduction

Conclusions

References

Tables

Figures

14

$\rightarrow$

Back

Close

\section{Full Screen / Esc}

Printer-friendly Version

Interactive Discussion 


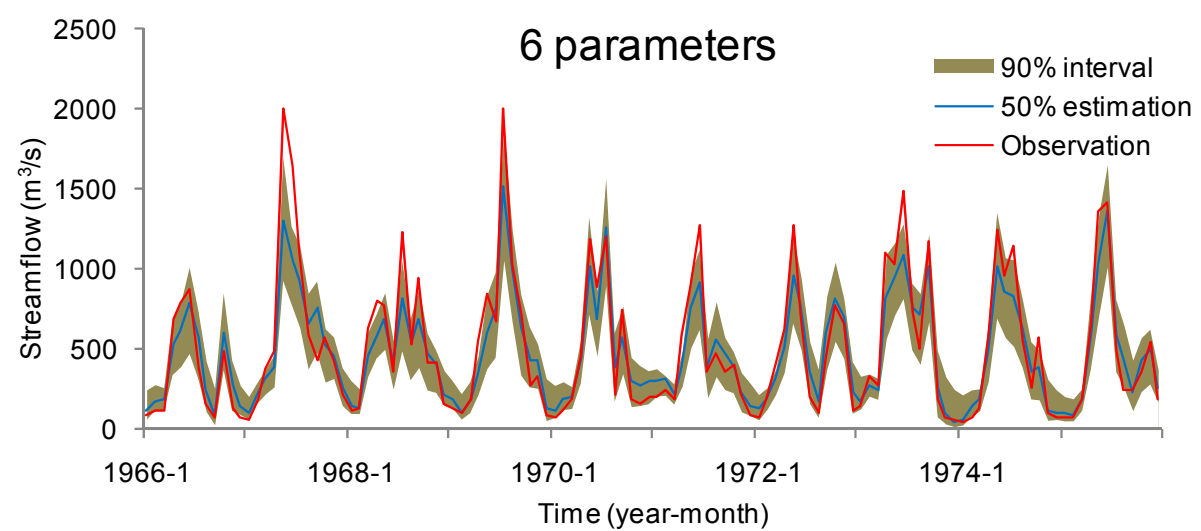

HESSD

8, 7017-7053, 2011

\section{Estimation of baseflow parameters of variable infiltration capacity model}

Z. Bao et al.

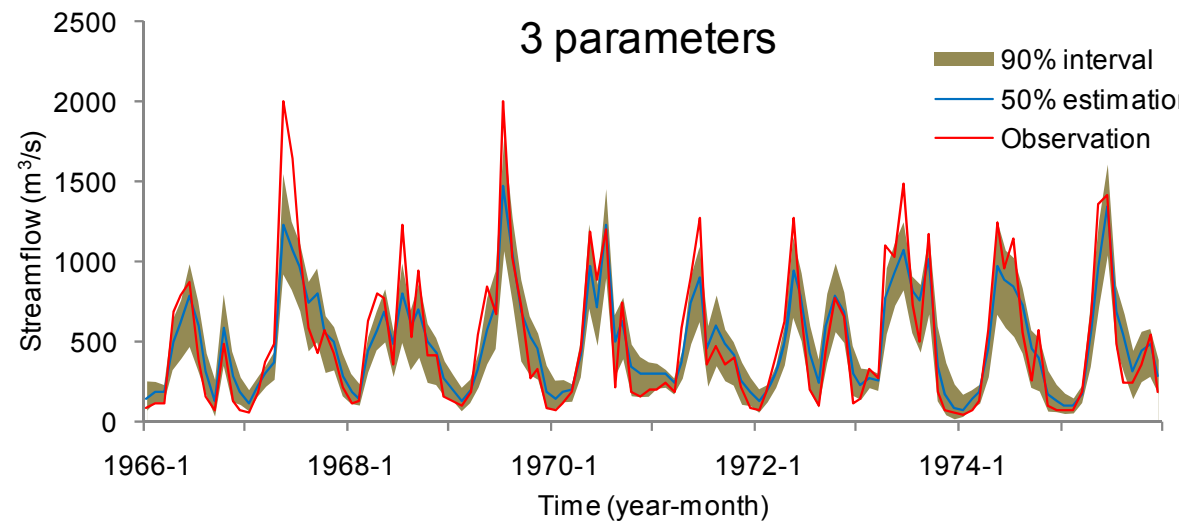

Title Page

Abstract

Conclusions

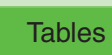

14

4

Back
Introduction

References

Figures

$\rightarrow 1$

$>$

Close

\section{Full Screen / Esc}

Printer-friendly Version

Fig. 8. The $90 \%$ confidence interval and $50 \%$ estimation for sim
catchment by two kinds of parameters setting methodologies.

Interactive Discussion 
HESSD

8, 7017-7053, 2011

\section{Estimation of baseflow parameters of variable infiltration capacity model}

Z. Bao et al.

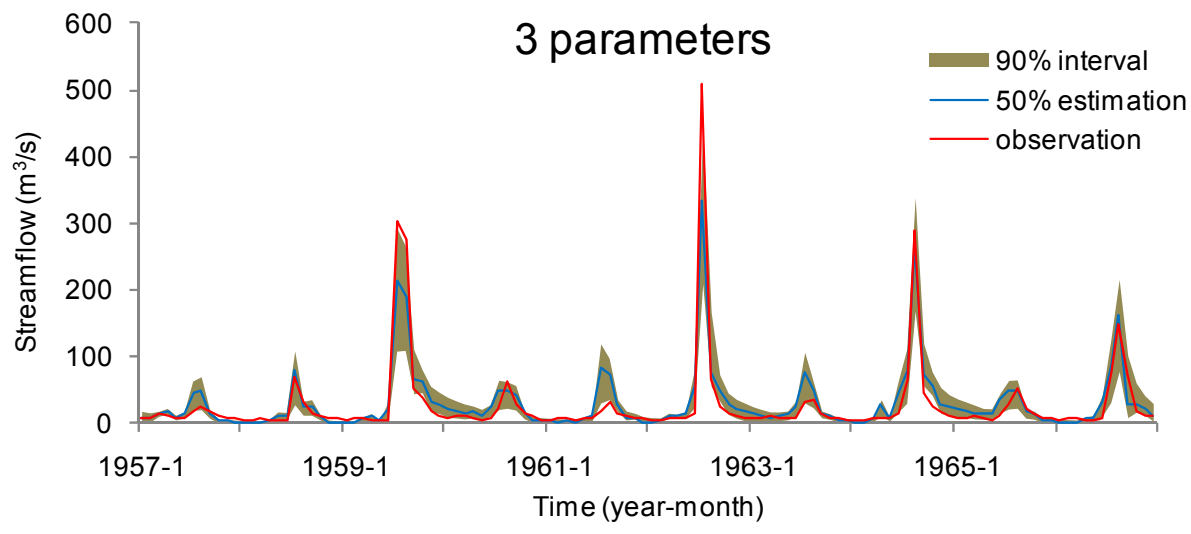

Title Page

\section{Abstract}

Conclusions

Tables

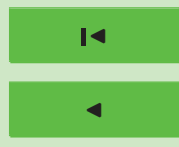

Back
Introduction

References

Figures

$\rightarrow 1$

$\checkmark$

Close

Full Screen / Esc

Printer-friendly Version

Interactive Discussion 


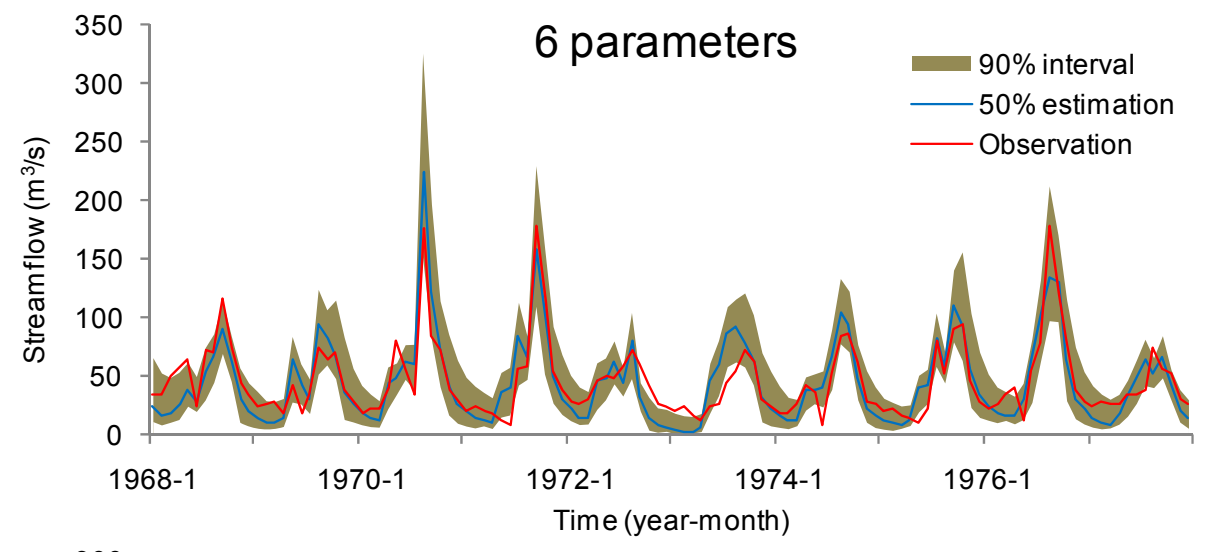

\section{HESSD}

8, 7017-7053, 2011

\section{Estimation of baseflow parameters of variable infiltration capacity model}

Z. Bao et al.

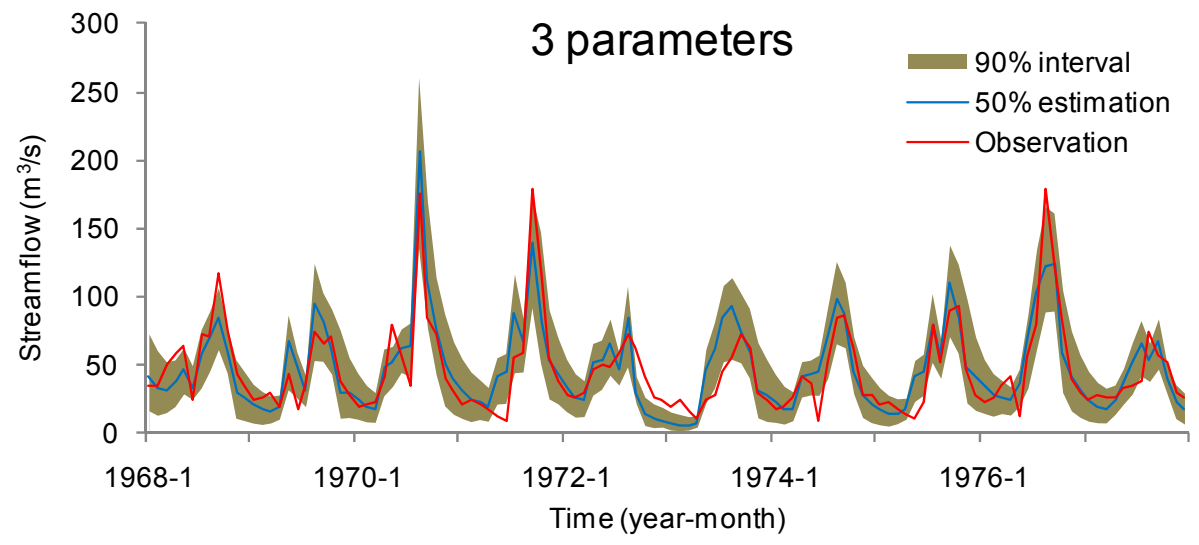

Fig. 10. The $90 \%$ confidence interval and $50 \%$ estimation for simulated streamflow in Minhe catchment by two kinds of parameters setting methodologies.

Title Page

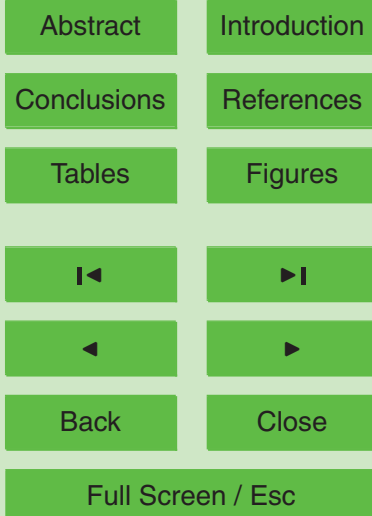

Printer-friendly Version

Interactive Discussion 


\section{HESSD}

8, 7017-7053, 2011

\section{Estimation of \\ baseflow parameters \\ of variable infiltration \\ capacity model \\ Z. Bao et al.}

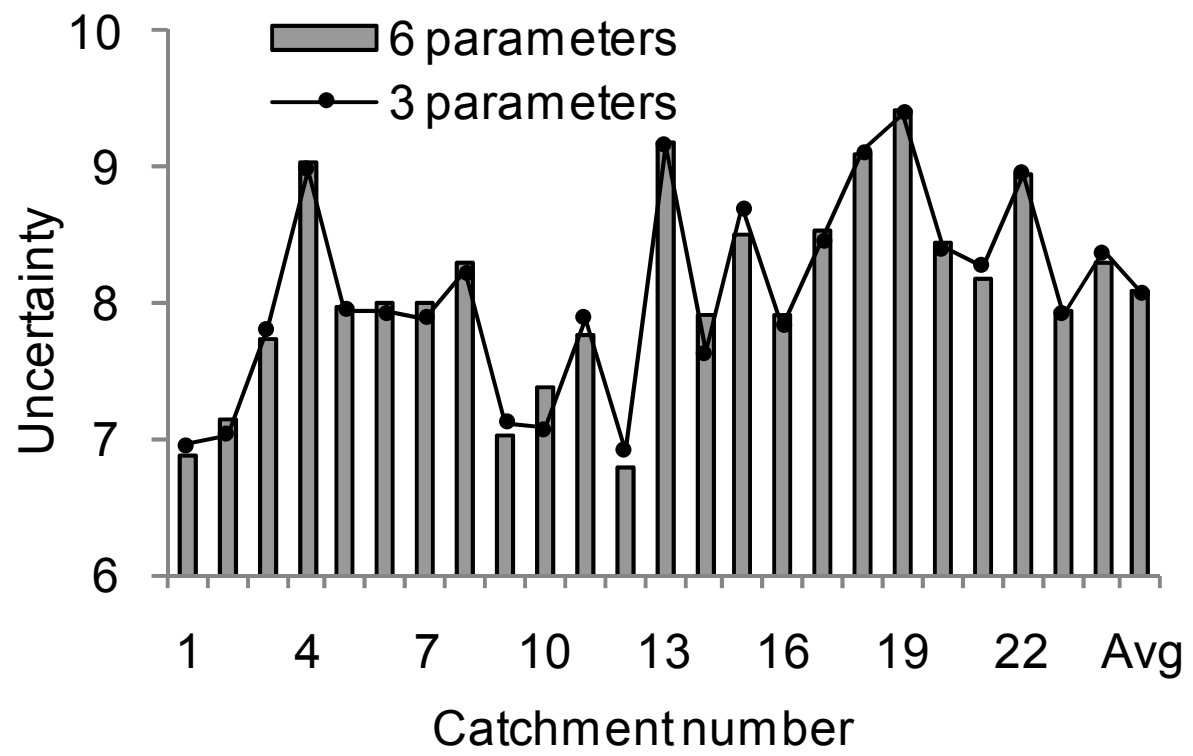

Fig. 11. Uncertainty of streamflow simulation by two kinds of parameters setting methodologies.

\section{Abstract}

Introduction

Conclusions

References

Tables

Figures

14

$\rightarrow$

4

Back

Close

Full Screen / Esc

Printer-friendly Version

Interactive Discussion
Title Page 